\title{
LA VOZ DE LOS MUDÉJARES DE LA ALJAMA DE GUADIX (1490-1500)
}

\author{
Manuel Espinar Moreno*
}

\section{INTRODUCCIÓN}

Los mudéjares del reino de Granada han sido estudiados desde diversas perspectivas pero todavía existen lagunas en la investigación histórica que hay que ir solventando. La progresiva castellanización, las Capitulaciones asentadas con aljamas y comunidades musulmanas, los distintos aspectos jurídicos, problemas económicos y tributarios de los sometidos, lucha religiosa, conversiones de los elementos más representativos, choques con los repobladores, inconvenientes respecto a las ventas y compras de propiedades, conflictos sociales dentro y fuera de los grupos mudéjares, estructura de la población, uso de la lengua, vestidos, etc., han ido guiando los trabajos de los investigadores pero hoy, la voz de los mudéjares y moriscos nos permiten conocer nuevos datos de la vida individual y colectiva de aquellas poblaciones.

Para Guadix y su tierra se cita una población de 300-450 vecinos y en el Cenete unos 1.160, mientras que todo el reino alcanzaba $\mathbf{1 7 0 . 0 0 0}$ individuos a finales del siglo XV. La convivencia cristiano mudéjar estaba basada en las Capitulaciones y acuerdos tomados localmente. Los concejos mudéjares tuvieron un gran papel en el funcionamiento de las ciudades y poblaciones. La población mudéjar se concentró en zonas de señorío o de realengo y se evitó su concentración junto a las costas. La organización mudéjar de Guadix y su tierra dependió de la sublevación de 1490, salieron los musulmanes de la ciudad y se asentaron en los lugares cercanos. Más tarde el barrio de la Morería de Guadix estará poblado por moros, unos aljamiados y otros no. En el momento de la conquista y la posterior sublevación algunas familias perdieron sus bienes y juegan un importante papel los judíos.

El funcionamiento de la Morería de Guadix ha quedado reflejado en la documentación cristiana sobre todo en los Archivos de Protocolos Notariales.

* Universidad de Granada. 
En ellos encontramos alusiones a la aljama o comunidad de Guadix y a otros individuos de las poblaciones cercanas, arrendamientos de hornos, tierras, casas, carmenes, deudas de seda, compras y ventas de paños, animales, árboles, cuido de las viñas, penas a los moros borrachos, etc., que nos sirven para ver como una buena parte de los mudéjares no sabían castellano y necesitan presentarse ante los escribanos cristianos con sus intérpretes. Entre ellos se citan algunos de los mudéjares más importantes de Guadix y algunos genoveses que sabían árabe. Entre estos documentos se citan mezquitas en funcionamiento y otras en construcción como es el caso de la de las tierras del Bejarín. Las costumbres ancestrales musulmanas en el arrendamiento de las tierras y la importancia de los animales de labor y la seda han quedado reflejadas en estos documentos. Es curioso cómo los mudéjares cuando tratan con los cristianos renuncian a sus fueros y a sus leyes destacando su xara y çunna. Cuando la relación contractual es entre ellos se mantienen muchas de las costumbres antiguas, necesitan el intérprete para que el escribano cristiano redacte el documento. Otras veces los mudéjares dan poderes a los cristianos para que los representen en juicios o cobren deudas. En otras ocasiones cuando la relación es con un cristiano salen otros mudéjares como fiadores de sus correligionarios. También algunos personajes como Hamete Uleylas tenía por merced de los Reyes Católicos el alguacilazgo y el almotacenazgo de los moros de la ciudad y su tierra, conocemos el cadí Abenchapela para las tierras del Cenete, las rentas de los borrachos, rescates de cautivos, papel de algunos negros aljamiados. La aljama de Guadix redacta un contrato con el bachiller Galán para que los defienda y a las poblaciones del término, les asesorará y ayudará en todos los problemas legales con la justicia de los cristianos. El uso de la pesa morisca de Guadix en las transacciones y el papel de los genoveses en el comercio es otro de los capítulos más interesantes de esta comunidad o aljama accitana.

\section{LA TOMA DE GUADIX. LAS CAPITULACIONES Y EL PROBLEMA MUDÉJAR}

La campaña de 1489 se centra en el cerco de Baza, Almería y Guadix ${ }^{1}$. La entrega de estas ciudades y sus territorios es la culminación de varias

1. Para la Guerra de Granada en general y para sus diferentes campañas cf. las siguientes obras. Garrido AtienzA, Miguel: Las Capitulaciones para la entrega de Granada, Granada, 1910; LAdero QuesadA, Miguel Ángel: Los mudéjares de Castilla en tiempos de Isabel I, Valladolid, 1969; id., Milicia y economía en la guerra de Granada: el cerco de Baza, Valladolid, 1964; id., España en 1492. Ed. Hernando, Madrid, 1978; id., Castilla y la conquista del reino de Granada, Valladolid, 1967; CARriazo y Arroquía, Juan de Mata: Historia de la Guerra de Granada, en Historia de España, dir. por R. Menéndez Pidal, Madrid, 1968, tomo XVII-1; Moreno Casado, José: Las Capitulaciones de Granada en su aspecto jurídico, Granada, 1949; 
campañas. La guerra psicológica aparece de nuevo. Se busca que se entreguen las ciudades sin realizar grandes esfuerzos guerreros que destruyen al enemigo y se intenta que los contendientes logren un acuerdo. Durante el cerco de Baza conocemos acciones caballerescas por ambos bandos, salidas hasta tierras del Cenete, enfrentamientos con los de Guadix, etc., el resultado será que Baza capituló y gracias a ello se entregaron las otras dos ciudades que estaban bajo el control del Zagal.

Conocidas las intenciones de entregar la ciudad por parte de Cidi Yahya comenzaron las negociaciones. La entrevista de Don Gutierre de Cárdenas y el caudillo bastetano se hizo bajo unas garantías militares, en un lugar medianero entre las murallas y el campamento cristiano. Las razones de don Gutierre las recoge el cronista Hernando del Pulgar, son importantes para conocer la guerra psicológica y las resume de la siguiente manera: que se enfrentaban a un enemigo más fuerte; que los reyes estaban dispuestos si se entregaban a ser generosos con los vencidos; que era necesaria la paz y no la guerra; que se evitarían muertes; que el auxilio esperado de otros lugares no llegaría; que los cristianos no levantarían el cerco pues estaban edificando casas para seguir allí aunque llegara el invierno; que seguían llegando mas refuerzos cristianos; que las provisiones y dineros estaban aseguradas pues los nobles y la Iglesia estaban colaborando con los reyes, etc. Todas estas razones las expone al musulmán diciéndole que él no las tiene, le argumenta que piense lo que ocurrió en Málaga y, además, como caudillo tenía la obligación de cuidar a sus súbditos. El consejo final es que entregue la ciudad mediante Capitulaciones que garantizan los reyes: "todos los que estáis en ella seréis guardados como sus súbditos, é naturales en vuestra ley y en

Segura Graíño, Cristina: Bases socioeconómicas de la población de Almería (Siglo XV), Madrid, 1979; LOPEz DE COCA, José Enrique: «El reino de Granada, 1354-1501», en Historia de Andalucía, III, Andalucía del Medievo a la Modernidad (1350-1504), Ed. Planeta, Barcelona, 1981, pp. 315-485; Eguílaz YANGUAS, Leopoldo: Reseña histórica de la conquista del Reino de Granada por los Reyes Católicos según los cronistas árabes, Granada, 1986, reed. de 1894; ANÓNIMO: Historia de los hechos de don Rodrigo Ponce de León, marqués de Cádiz, en CODOIN, CVI; BENAVIDES, A.: Memoria sobre la Guerra del reino de Granada, MRAH, VIII; Crónicas de los Reyes de Castilla desde don Alfonso el Sabio hasta los católicos don Fernando y doña Isabel. Colección ordenada por don C. Rosell, tomo III, Madrid, 1953; Crónica de Hernando del Pulgar; ESPINAR MORENo, Manuel: «Bienes donados por don Enrique Enríquez al monasterio de Santa María de la Piedad de Baza (1492-1493) en Cúllar», Homenaje al Dr. Vallecillo Avila, Granada, 1985, pp. 261-279; id., "La convivencia de cristianos viejos y nuevos en Baza y su tierra. Problemas de mantenimientos (Carne, pescado y otros productos)", Actas II Congreso Internacional de las Tres Culturas, Toledo, 1985, pp. 125-155; id., "El agua y la tierra en Guadix desde la Baja Edad Media hasta la expulsión de los moriscos», Actas del I Coloquio de Historia, Guadix (1989), pp. 13-36, cf. p. 23; Espinar Moreno, Manuel, Ruiz Pérez, Ricardo y RuIz PÉrez, Rafael: Documentos para el estudio del Marquesado del Cenete (14621542), Vol. I, Granada, 1985. Albarracín Navarro, Joaquina, Espinar Moreno, Manuel, Martínez Ruiz, Juan y Ruiz Pérez, Ricardo: El Marquesado el Cenete. Historia, Toponimia, Onomástica según documentos árabes inéditos, 2 Vols., Universidad-Excma. Diputación Provincial de Granada, Granada, 1986. 
vuestra libertad, y en la posesión de vuestros bienes, como la facen á los que de su grado se han puesto en sus reales manos" 2 .

Cidi Yahya se compromete a responder cuando lo consulte con los ciudadanos y con los viejos de la ciudad. Los viejos, capitanes y ciudadanos de Baza determinaron consultar la rendición que les proponía su caudillo con el rey de Guadix. Le expondrían al Zagal que los mantenimientos y fuerzas cristianas iban en aumento mientras que ellos estaban en situación límite. Pensaron enviar a Guadix al alcaide de Baza, Muley Hacen, el Viejo, para que se entrevistase con el Zagal.

Con todo ello el alcaide se encaminó a Guadix y expuso al Zagal lo hablado entre los bastetanos: problemas de alimentos, asedio de seis meses, numerosos muertos en los combates, heridos, enfermos, falta de armas y pólvora, necesidad de nuevos contingentes armados, etc., diciendo que si el Zagal se comprometía a enviarles ayuda ellos no iban a entregarse: "Allende de esto le dixo, que debía considerar quantas cibdades é villas de aquel Reyno eran perdidas, é quantos de sus moradores vencidos é captivos, los campos destruidos, la cavallería destrozada, las riquezas del Reyno perdidas y enagenadas; e que en todas las cosas pasadas habían experimentado la ventura que siempre habían fallado contraria".

Tras escuchar las razones el Zagal contestó al alcaide de Baza que lo consultaría con los alfaquíes y viejos de Guadix para saber qué tenía que hacer. Consultado el problema con los más influyentes de Guadix vemos los distintos grupos y sus intenciones: poderosa.

- Unos creían que debía de consultarlo con Granada, ciudad grande y

- Vista la necesidad en que estaban los de Baza los accitanos debían de disponerse a tomar las armas.

- Todos juntos sumarían un gran número y podrían socorrer a los bastetanos.

- Estarían dispuestos todos al peligro de la guerra de confrontación entre musulmanes y cristianos.

- Si Baza se entregaba todo el resto del reino lo haría y los musulmanes lo perderían todo.

2. Espinar Moreno, Manuel: «Las ciudades de Baza, Almería y Guadix. Su relación con Granada a finales del dominio musulmán. De la toma de Constantinopla a la Capitulación de Guadix», en Tres Estudios sobre Guadix y su tierra (Del Guadix romano al morisco), Guadix, 1990, pp. 35-76. ESPINAR MorENO, Manuel y Grima CERVANTES, Juan A.: «Un personaje almeriense en las crónicas musulmanas y cristianas. El infante Cidi Yahya Alnayar (1435?-1506): su papel en la Guerra de Granada", Boletin del Instituto de Estudios Almerienses, 7 (Almería, 1987), pp. 57-83. Recientemente se ha estudiado el sistema defensivo que los cristianos pusieron sobre la ciudad bastetana, cf. MARTín GARCíA, Mariano: «El cerco de Baza. Los restos conservados» Alzada, 32, Colegio Oficial de Aparejadores y Arquitectos Técnicos de Granada, 1994, pp. 33-39. 
Otro grupo expuso distintas razones y añaden que los de Granada no les iban a ayudar. Dejan claro que algunos de los más principales de Guadix habían pedido ayuda a los granadinos y ésta no llegaba. Ellos, en consecuencia, no podían hacer nada frente a los cristianos, ni ayudar a los sitiados. En resumen son partidarios de entregarse: "Por ende dixeron, que debían los de Baza ganar seguridad del Rey don Fernando é de la Reyna Doña Isabel para sus personas é bienes, é que les debían entregar las fuerzas de la cibdad".

El Zagal entendió que el deseo de resistir no se compaginaba con sus posibilidades de hacer guerra, por ello comunicó al alcaide de Baza que hicieran lo que más les interesara siempre que defendiera los intereses de los bastetanos en bienes y personas. Los de Guadix vieron cómo sus hombres más principales estaban de acuerdo en que Baza se entregase y que su rey no tenía fuerzas ni medios para el combate. Entre el pueblo comenzaron a surgir enfrentamientos: "luego la gente común se alteró, é la seguridad que de largos tiempos habían gozado se convirtió en tristeza, considerando como habían de mudar la servidumbre que tenían antigua, é venir nuevamente á subjeción de rey ageno de su ley é de su lengua" ${ }^{\prime 3}$.

Algunos de Guadix defendían que había que luchar por la ley y la libertad del Islam por lo que era necesario tomar las armas. Otros viendo las escasas fuerzas y posibilidades defendían ponerse bajo la sujección de los cristianos: "E con esta diversidad de votos, ovo entre ellos grandes escándalos; porque privados del entendimiento con la súbita mudanza, no pensaban tener lugar seguro, ni amigo cierto que los amparase, ni sabían procurar paz, ni seguir guerra, ni los consejos de sus mayores tenían autoridad, ni con la turbación sabían discernir lo que les sería más seguro. E todos vagando acá é allá, llenos de miedo, é privados de toda buena razón, preguntaban sí podían haber seguridad de la vida"4.

Los principales de la ciudad intentaron aplacar al pueblo y a los que querían tomar las armas contra los cristianos argumentando: "Conoscida por los principales de la ciudad aquella confusión, con palabras de seguridad é de paz prometieron de les haber toda libertad de sus personas é pacífica posesión de sus bienes, é que permanecerían en la ley de sus padres. E con estas promesas, el pueblo que ligeramente se mueve á todas partes, cesó de aquella alteración en que estaba" ${ }^{\prime \prime}$.

Al poco tiempo volvió a Baza el enviado por Cidi Yahya a Guadix, Muley Hacen, el Viejo, y le manifestó que el Zagal estaba de acuerdo con lo tratado con los reyes cristianos. La entrega de Baza era una realidad y ésta se

3. Pulgar, Hernando del: Crónica de los señores Reyes Católicos don Fernando y doña Isabel de Castilla y de Aragón escrita por su cronista Hernando del Pulgar, cotejada con antiguos manuscritos y aumentada de varias ilustraciones y enmiendas, p. 501.

4. Ibidem.

5. Ibidem. 
efectuó el 4 de diciembre de 1489. Las negociaciones entre don Gutierre de Cárdenas y Cidi Yahya continuaron e hizo de intérprete Juan de Almaraz. Tras aquellas conversaciones se estipularon las condiciones de las Capitulaciones de Baza. Los musulmanes quedaban en los arrabales, viviendo en su ley y con sus haciendas y con la condición de mudéjares ${ }^{6}$. Se entregaron varios lugares junto con la capital bastetana entre las que destacó Caniles y Purchena, esta última lo hizo a manos de su alcaide Alí Aben Fahar, quien dio muestras de su valor y entereza al dirigir unas emotivas palabras a los reyes cristianos. Pídió que se respetarán los bienes y personas de los habitantes de Purchena, y que a él se le diera permiso para pasar a tierras africanas.

Faltaba Guadix y Almería para poseer todo el territorio que formó el reino del Zagal, por ello, se encargó al caudillo al-Nayar que hiciera las gestiones pertinentes para acelerar el proceso. Cidi Yahya había comunicado al Zagal que el destino del reino era inamovible y que la ruina de aquella entidad política era una realidad. Sin embargo, un documento fechado el 15 de noviembre de 1489 nos aclara detalladamente la intención de don Fernando y el papel de mediador que estaba desarrollando Cidi Yahya.

Cuando envía la carta don Fernando al caudillo general de Baza y Almería le dice que fue para él muy grato conocer la voluntad de negociación de Cidi Yahya, que los acuerdos tomados entre el comendador mayor de León y el caudillo musulmán se respetarian: "en lo cual no debéis tener duda ni confusión, sino creer lo que tan manifiestamente os muestra para vuestro bien y de vuestra gente y la terminación que nos ha dicho tenéis de no asentar partido alguno sin dar parte al rey de Guadix, vuestro cuñado. Estamos muy ciertos que él no tendrá en esta más voluntad que la vuestra, en especial al cabo de tanto tiempo y muerte de tanta gente".

Le pide el monarca cristiano que sus efectivos guerreros los ponga a disposición de los castellanos, y, le ruega que no dé lugar a que sucedan he-

6. Sobre la convivencia y asimilación del elemento mudéjar y más tarde morisco en la sociedad castellana puede consultarse: LADERO CuESADA, M. A.: Granada después de la conquista. Repobladores y mudéjares, Granada, 1988; id., «La repoblación del reino de Granada anterior al año 1500», Hispania, 110 (Madrid, 1968), pp. 489-563; id., «Mercedes reales en Granada anteriores al año 1500», Hispania, 112 (Madrid, 1969), pp. 355-424; id., "Defensa de Granada a raíz de la conquista (1492-1501)», Homenaje a Elías Serra Rafol, Universidad de la Laguna (1974), IV, pp. 97-131; id., Los mudéjares de Castilla en tiempos de Isabel I, Valladolid, 1969; id., Castilla y la conquista del reino de Granada, Valladolid, 1967; Münzer, J.: «Viaje por España y Portugal en 1494 y 1495», B.R.A.H., LXXXIV (1924), pp. 32-120 y 197-280, ed. de Julio Puyol; Ladero Quesada, M. A.: Granada. Historia de un país islámico (1232-1571), Gredos, Madrid, 1989 con abundante bibliografía para este largo período. Además MÁRMOL CARVAJAL, L. del: Historia del rebelión y castigo de los moriscos del reino de Granada, BAE, XXI, vol. I, Madrid, 1946, pp. 147-150 sobre las capitulaciones. Además cf., GALÁN SÁNCHEZ, A.: Los mudéjares del Reino de Granada. Granada, 1991 y la numerosa bibliografía que sobre los mudéjares se recoge en Aljamía. Boletín de Información bibliográfica. Mudéjaresmoriscos-Textos aljamiados. Filología Arabo-Románica. Universidad de Oviedo, hasta ahora 6 números publicados. 
chos extraños que desvirtúen lo acordado entre ambas partes: "no lo debéis dilatar a que subcedan novedades que lo estorben y a Dios rogamos sobre todo por la brevedad. Y para el día que nos avisaredes volverá el Comendador mayor de León, y todo lo que el os habló y ofreció de nuestra parte se cumplirá a contento vuestro".

En medio de estos problemas se van a suceder una serie de hechos de extraordinaria importancia para Cidi Yahya. Desde el día 22 en que Almería pasó a los cristianos hasta el 30 que lo haría Guadix, conocemos que nuestro personaje obtuvo de los monarcas un documento donde se le reconocían los bienes y hacienda tratados con don Gutierre de Cárdenas, hizo negociaciones con algunos alcaides del Cenete, y también en estos días se convirtió al cristianismo junto con algunos de sus familiares más directos. También ocuparon los cristianos las poblaciones de Almuñécar y Salobreña. Los reyes eran conscientes de que si expulsaban de los lugares cercados a los musulmanes la tierra se despoblaría, por ello pidieron consejo para dejarlos como mudéjares con sus mujeres, hijos y bienes.

El 25 de diciembre se produce un hecho trascendental para la futura vida de Cidi Yahya, se le reconocen unas capitulaciones personales y se le bautizó mientras se tenía puesto el real cerco de Almería. En el documento se le nombra "caudillo y general de los moros de Baça e Almería e alcayde de ella". Se alude a las cuestiones tratadas entre él y don Gutierre de Cárdenas referidas a la persona y familiares del defensor de Baza "tocantes a vos e a vuestro hijo e a los de vuestro linage que no se pusieron en el asiento tocante a los vezinos y comunidad de la çibdad de Baça por la priesa que a mi ynstancia e por me serbir distes a la entrega de ella".

Los principales de la ciudad de Guadix aplacaron a la muchedumbre diciéndoles que todo estaba garantizado, tendrían libertad en sus personas, se les garantizaba la posesión de los bienes y conservarian lengua, religión y costumbres. El pueblo se volvió a sus casas y sólo había que esperar que los cristianos hicieran su entrada en la ciudad por el camino de Almería donde estaban para recibir el señorío de la ciudad vecina.

El paso de las tropas se hizo por Fiñana y otras poblaciones donde se fueron entregando todas aquellas villas y núcleos de población. Sin embargo, tenemos que decir que en algunas de estas villas y ciudades se produjeron enfrentamientos con las tropas cristianas ${ }^{7}$.

La entrega de las fortalezas del Cenete no debió adquirir especial dramatismo, dada su condición de pequeñas poblaciones. El hecho material debió transcurrir durante el paso del Real a través de su término, puesto que desde Almería a Guadix se cruzó la meseta del marquesado, haciendo noche

7. Hemos puesto de manifiesto en otros trabajos que aunque capitularon Abla, Fiñana $y$ Abrucena algunos musulmanes se enfrentaron a los cristianos. 
en Fiñana el 29 de diciembre. A pesar de que no es frecuente que las crónicas aporten noticias sobre la entrega de plazas menores o de poca importancia estratégica, hemos encontrado algunos pasajes que directa o indirectamente nos dan un conocimiento puntual de la efemérides. En este sentido, Pedro Mártir de Anglería, sitúa la rendición de la comarca incluso antes de la entrega de Almería, cuando el ejército acampaba cerca de Tabernas:

"Acampamos en su llanura, a fín de que se reuniera el resto de las fuerzas rezagadas, quedándonos allí un día entero y dos noches. Se nos trae la noticia de que por medio del Conde se han sometido al poder real las plazas de Abla, Calahorra, Fiñana, Serga y Abrucena, cada una con las aldeas vecinas situadas en el contorno de Guadix, por consejo del Virrey, a quien toda aquella región tenía gran respeto. A la misma hora llegó desde Guadix, montando en su corcel, un ilustre caballero enviado por el Zagal para que le anuncie al Rey que el otro Rey vencido viene en son de súplica a su vencedor. Para que le resulte más breve el camino al Zagal, que ya está en marcha y para la ejecución de los planes del Rey, salió este del campo de Tabernas el día 23 de diciembre".

Sea cual sea la fecha de entrega y capitulación del Cenete, o incluso si se contó con una capitulación especial, lo que hay que destacar es que los castillos y villas pasaron a manos cristianas en opinión de los cronistas, bien tras la rendición de Baza tras la toma de Almería cuando los Reyes Católicos venían de aquella ciudad hacia Guadix el 29 de diciembre, o bien días antes en el real de Tabernas, con lo que se invierte en cierta manera el camino seguido por las tropas, como decíamos, sea cual fuere la fecha, las justicias y capitanes musulmanes buscaron mercedes para ellos y sus familiares. Ejemplos de estos tenemos en el rey de Guadix, el Zagal, el alfaquí Abdala Zuleygui y sus familias el 10 de diciembre antes de entregar la ciudad o Yahia al- Nayar el 25 del mismo mes, otras mercedes obtuvo el 1 de enero de 1490 el secretario del Zagal, Abrahem Azeyt para él y sus allegados ${ }^{8}$.

La ocupación militar de los diversos castillos y torres defensivas por parte cristiana llevó a evitar levantamientos populares, dejaba a los monarcas castellanos como señores de las nuevas tierras y la población musulmana se atendría a las capitulaciones generales que se dieron en Ecija el 11 de febrero de 1490, válidas para la mayoría de las tierras de Almería y de Guadix de las que creemos no escapó el Cenete.

Los cristianos hicieron su entrada en Guadix el 30 de diciembre de 1489 , miércoles, por la tarde ${ }^{9}$. Frente a la ciudad pusieron su campamento y

8. En carta de 1 de enero de 1490 los monarcas en reconocimiento de la colaboración del secretario del Zagal le reconocen a él y a sus familiares más directos exención de derechos y mercedes que no gozaban los otros moros vasallos, cf. LADERO QUESADA, M. A.: Los mudéjares..., doc. 32, pp. 139-140.

9. Cf. Asenjo SeDANo, Carlos: Guadix la ciudad musulmana del siglo XV y su transformación en la ciudad neocristiana del siglo XVI, Granada, 1983, id., Guadix. Estudio de una ciudad mudéjar. 
tienda real, posiblemente en la Xarea árabe. El Zagal les entregó al rey y a la reina la alcazaba y otros lugares de la ciudad accitana "é todas las fuerzas, é torres é puertas de la cibdad de Guadix; é dieron la tenencia de la fortaleza é la capitanía de aquella cibdad á Don Hurtado de Mendoza Adelantado de Cazorla"10. Desde aquí el rey escribió al bayle de Valencia notificándole que Guadix se había rendido. Otros autores como A. de la Torre nos dicen que las tropas llegaron a Guadix el día 29 de diciembre y que se tomó el día 30.

Andrés Bernáldez resalta que las Capitulaciones asentadas con el Zagal y sus allegados eran un secreto entre los reyes: "é llegando luego el rey Muley Baudili é sus alcaydes, entregaron la ciudad é fortaleza, é alcazaba, é fuerzas de Guadix al Rey Don Fernando, el qual fizo bastecer luego muy bien la fortaleza, é dejó allí guarnición é buen recaudo. É los partidos de estas ciudades, villas, é lugares eran secretos entre los Reyes, empero lo que se alcanzó á saber era, que los moros quedasen mudéjares en sus haciendas, dejando las ciudades cercadas, que no viviesen dentro, salvo en los arrabales y en las alcazabas; é donde quiera que había fuerza ó fortaleza, que no viviesen, salvo en los llanos; é quedó el Rey Muley Baudili por Señor é Rey de Fandarax, que es una villa fuerte de trescientos vecinos, con otros lugares é alquerías en su comarca, é por vasallo del rey de Castilla; é estovieron en Guadix Jueves y Viernes, é partióse el Rey moro para Fandarax"11.

Sin embargo, en el texto de las Capitulaciones encontramos noticias interesantes para entender lo que ocurre tras la entrada de las tropas al instaurarse una nueva sociedad cristiano-mudéjar. El texto dado en Ecija el 11 de febrero de 1490, se puede resumir así:

Es una Capitulación con Almería, las villas, lugares y tierras que se entregaron juntamente con ella. El rey y la reina expresan que asentaron con ellos que se entregasen en término de sesenta días. Los toman y reciben bajo su amparo, seguro y defensa. Prometen dejarlos vivir en sus casas y respetarles sus haciendas. Conservan su ley y no les apremiarán a seguir ni guardar otra "e les dexaremos y mandaremos dexar sus almuédanos, e algimas, e alfaquíes, y serán judgados por su ley xaraçuna, con consejo de sus alcadis, se-

Cómo se ocupó, repartió y organizó la ciudad tras la capitulación con los Reyes Católicos, Granada, 1992. EsPINAR MORENO, Manuel: «Estudios sobre las iglesias de Guadix y su diócesis con motivo del V Centenario (1492-1992). Dotación de los Reyes Católicos y Doña Juana», Boletín del Instituto "Pedro Suárez", V, Guadix, 1992, pp. 27-37. EsPinAR Moreno, M., QueSAda Gómez, J. J. y SÁez MEdina. J.: «La villa de La Peza. De lo musulmán a lo cristiano. 1: El ejemplo de la mezquita convertida en Iglesia y otros materiales", Boletín del Instituto "Pedro Suárez", V, Guadix, 1992, pp. 39-50. EsPINAR MORENO M.: «Habices y diezmos del obispado de Guadix. Pleito con los marqueses del Cenete (1490-1531)», Revista del Centro de Estudios Históricos de Granada y su Reino, 6, (1992), pp. 255-275.

10. Pulgar, Hernando del: Crónica de los señores Reyes Católicos.., p. 504.

11. BeRNÁldez, Andrés: Historia de los Reyes Católicos don Fernando y doña Isabel, escrita por el bachiller Andrés Bernáldez, cura que fue de la villa de los Palacios y capellán de don Diego Deza, arzobispo de Sevilla, pp. 636-637. 
gúnd costunbre de los moros, y que queden a las dichas mezquitas sus rentas, de la manera que antes las tenian"12. No se les llamará para trabajos y si lo hacen se les pagará su justo jornal y salario. Tampoco tendrán huéspedes en sus viviendas ni se les tomarán ropas. Se prohíbe a los cristianos entrar en casa de los mudéjares sin su permiso. Pagarán los derechos que entregaban a sus reyes moros y del aceite sólo entregarán el diezmo ${ }^{13}$. Conservarán los caballos y armas pero no las de pólvora. Tampoco llevarán señales distintivas. Los esclavos y rehenes los devolverán. Se les respetan los barcos para comerciar. Entregarán la parte de las herencias que daban los moros. Perdonan a los que cometieron acciones de guerra en defensa propia. Los nacidos de cristianas no serán convertidos hasta que tengan doce años y ellos escojan la religión que quieren. Los judíos y tornadizos no tengan jurisdicción sobre ellos.

12. Sobre habices hay una extensa bibliografía cf. ESPINAR MORENo, M. y MARTíneZ RUIZ, J.: Ugijar segín los Libros de Habices, Granada, 1983. Sobre la fiscalidad existe una gama de trabajos interesantes, puede cf. ÁlVAREZ DE CIENFUEGOS, I.: «Régimen tributario del reino mudéjar de Granada», MEAH, VIII (1959), pp. 99-124; GARZON PAREJA, M.: El arte de la seda en Granada, Granada, 1971; GAMIR SANDOVAL, A.: «Las fardas para la costa granadina», en Carlos V. Homenaje de la Universidad de Granada, (1958), pp. 293-330; GARRAD, K.: «La industria sedera granadina en el siglo XVI y su conexión con el levantamiento de las Alpujarras», MEAH, II (1956), pp. 73-104; MORENO OLMEDO, Ma . A.: «Contribución al estudio de la cuenca del Almanzora (Albox, farda)», Roel, 2 (1981), pp. 35-41; VINCENT, B.: «Las rentas particulares del reino de Granada en el siglo XVI: fardas, habices, hagüela», Dinero y Crédito (Siglo XVI-XIX), pp. 249-278, Alfonso Otazu, ed., Madrid, 1978; CAMPOS Daroca, M ${ }^{\text {a }}$ L.: «Las rentas particulares del reino de Granada tras la expulsión de los moriscos en 1570. La farda y la Renta de Población», Chronica Nova, 16 (1988), pp. 55-66; EsPinar Moreno, M. y otros: «Problemas fiscales de Almería y sus villas (Siglos XV-XVI). Las Capitulaciones de 15001501 y sus consecuencias», Congreso sobre Almería entre Culturas, siglos XIII-XVI, Almería, 1990, pp. 399-412. EsPINAR MORENO, M. y otros: «La iglesia en la repoblación de Guadix (Siglo XV). Dotación de los Reyes Católicos», Actas del I Coloquio de Historia, Guadix (1989), pp. 103-114; Espinar Moreno, M.: «Iglesias y ermitas de Baza en 1492. Dotación de los Reyes Católicos», CEM y CCTTHH, XVI-XVII (1988-1989), pp. 83-98.

13. Cf. las obras de Ladero Quesada citadas anteriormente y VINCENT, Bernard: «Economía y sociedad en el Reino de Granada», Historia de Andalucía. IV. La Andalucía del Renacimiento, Cupsa Editorial-Editorial Planeta, S.A., Barcelona, pp. 161-223; GARCía DE CORTÁZAR, J. A. y otros: Organización social del espacio en la España medieval. La corona de Castilla en los siglos VIII al XV, Ariel, Barcelona, 1985, en especial trabajo de López de Coca; GALlego Burín, A. y GamiR SANDOval, A.: Los moriscos del reino de Granada según el Sinodo de Guadix de 1554, Granada, 1968; DOMÍNGUEz ORTIZ, A. y VINCENT, B.: Historia de los moriscos. Vida y tragedia de una minoría, Madrid, 1978; Albarracín Navarro, J. y otros: El Marquesado del Cenete. Historia, Toponimia y Onomástica según documentos árabes inéditos, Granada, 1986, 2 vols. Además Bejarano ROBLEs, F.: La industria de la seda en Málaga durante el siglo XVI, Madrid, 1951. Espinar Moreno, M.: «Abulcaçen Aben Cohbe se convierte al cristianismo como Diego de Mendoza. El alguacilazgo de Purchena en manos de esta familia desde octubre del 1500 hasta 1568», Roel, 7/8 (1986/87), pp. 83-114. ESPINAR MORENO, M.: «La conversión al cristianismo de Mahomad Haçen y otros personajes en la zona de Baza. Motivos económicos», IV Congreso Internacional sobre mudejarismo, Teruel, 1987, pp. 481-493; Grima Cervantes, J. A.: «Las capitulaciones pactadas en 1488 y en 1501 entre los Reyes Católicos y los mudéjares de Vélez Blanco y Vélez Rubion, Rev. Velezana, 6 (Almería, 1988), pp. 77 y ss.; LAdERo Quesada, M. A.: Los mudéjares..., Albarracín y otros: El Marquesado del Cenete... 
Entre otras condiciones encontramos que si alguno sale a tierras extranjeras puede vender sus bienes en tres años. Los judíos gozan de lo mismo que los mudéjares. Si alguno se convirtió al islamismo no será obligado a ser cristiano contra su voluntad, si fue cristiano y se convirtió al judaísmo tiene un año para volver a ser cristiano. Los cristianos no entrarán en las mezquitas. Si algún cautivo huye y se acoge a las ciudades de Baza, Almería y Guadix será libre. Si quieren pasar a otras tierras musulmanas les ponen barcos, les dan permiso para vender sus bienes y en un año les reconocen los documentos que tienen. Entregarán el diezmo del ganado. Se les guardan a los alguaciles sus derechos como especificaban las cartas de los reyes de Granada. Se ordena asentar todo aquello al entregar las fuerzas y fortalezas de las ciudades, villas y lugares. Los nuevos vasallos jurarán obediencia a los monarcas y guardarán lo capitulado.

\section{LA SUBLEVACIÓN DE 1490}

El Zagal se convirtió en rey y señor de Andarax y otros territorios gracias a las Capitulaciones firmadas con los cristianos. La población sometida siguió viviendo en sus casas y en los barrios de la Madina y arrabales. En las vegas y alquerías continuaron aquellos pobladores dedicándose a la agricultura, ganadería y comercio. Salieron de la ciudad el caudillo Aben Zeyt y el alfaquí Ubecar que se exiliaron a Granada. El 26 de junio de 1490 se visitaron las tierras conquistadas en 1488 y 1489 para comprobar cómo estaban las defensas y si los pobladores respetaban el cumplimiento de las Capitulaciones. Más tarde vino el Zagal a ayudar a los cristianos en la lucha contra Boabdil en 1490. Desde Granada se incide en que hay que volver a vencer a los cristianos. En este sentido los granadinos, guiados por Boabdil, salen el 15 de julio de la capital y tras 4 días de cerco toman Alhendín, destruyen el castillo y consiguen gran cantidad de cautivos, envían ayuda a los enemigos del Zagal que se sublevan en las tahas Marchena y Alboloduy. Los dominios del Zagal peligraban y, además, un numeroso grupo de mudéjares de Baza, Guadix y Almería habían pactado con Boabdil para que les enviase socorros.

“En este tiempo se alzaron los más de los vasallos moros del Rey Baudili Alzagal, Rey de Fandarax, vasallo del Rey Don Fernando, é los moros de Guadix se cartearon con los de Granada, y tenían ordenado de matar á todos los christianos que estaban en la fortaleza, é de alzarse con ella, é con la ciudad por Granada; y algunos de los mismos moros, no siendo de ello contentos, lo revelaron; y el Marqués de Villena, que había quedado por Capitán general, entró allá con dos mil de á caballo, é asaz peones, é diciendo que iba a Fandarax á los lugares que se habían rebelado contra el rey Baudili Alzagal, hizo el viaje por la ciudad de Guadix, y aposentándose allí cerca de la fortale$\mathrm{za}$, bastecióla muy bien, é hizo salir todos los moros de la ciudad á facer alarde, é desque estuvieron fuera, fizo cerrar muy bien las puertas de la ciudad, é no dejó entrar en ella más los moros, salvo de dos en dos, é de tres en tres, les 
mandó que fueran á sacar sus mujeres é fijos, é hacienda, y así los echó todos fuera, y ellos quejabanse, y él decía que lo hacia con causa, que oviesen paciencia, que por lo que ellos ordenaban contra el servicio del Rey en esta ciudad, les mandaba salir de ella; é el Marqués con muy buenas razones les rogó que se aposentasen por ahí cerca, y que él escribiría al Rey sobre ello, para que los culpados fuesen castigados, é los sin culpa se volviesen á sus casas. É los moros se aposentaron en las huertas, é por eso enviáronse á quexar al Rey de el Marqués de Villena, é el Rey les envió á decir desde Córdoba, que no oviesen enojo, que él volvería muy presto á Guadix, é les guardaría su justicia, y volverían á sus casas" 14 .

El rey salió de Córdoba el 20 de Agosto de 1490 hacia la Vega de Granada, luchó contra los sublevados y los venció, envió tropas para que levantasen el asedio de Salobreña. Entre tanto don Fernando desvió el camino y se dirigió a Guadix para solucionar aquellos problemas:

"é fué la vía de Guadix, donde el Marqués de Villena estaba, é hizo pesquisa de la traición que los moros ordenaban, primero que el Marqués los sacase de la ciudad, é supo la verdad de todo, é los moros le suplicaron, quejándose del Marqués de Villena, que les dejase entrar á vivir en sus casas, como les había prometido, é el Rey les respondió, diciendo: "Amigos, yo soy bien informado de la traición que entre vosotros me teniades ordenada, de matar mi alcaide é escuderos, que guardaban mi Alcazaba, y alzaros con ella, é con la ciudad contra mí, por el Rey é común de Granada; por esto veis que sois dignos y merecederos de grandes penas; empero porque no digais que no uso con vosotros de piedad, y que no vos quiero oír justicia, á mí place que sea de esta manera: que se haga pesquisa más larga é más en forma, y que todos los que se hallaren culpados padezcan por ello, é que los que no, sean libres; é de cierto os fago saber y digo, que no miréis que de quantos fallare culpados no ha de escapar uno; por ende, yo vos doy plazo para que os vais é escojáis de dos cosas una; lo que dicho tengo, ó que os vais con vuestras mujeres, é fijos é vecinos, donde quisiéredes, é yo vos mandaré poner en salvo, ó me entregaréis todos los que eran en esta traición, para que haga justicia de ellos, é sabed que no ha de escapar ninguno de ellos". É los moros de Guadix, como todos, ó la mayor parte de ellos, fuesen culpados ó consentidores de la traición que ordenaban, habido su consejo é acuerdo sobre ello, pidieron por merced al Rey que los dejase ir libres con todo lo suyo po dó quisiesen, y quedase con su ciudad, y el Rey los envió seguros á cada uno con lo suyo donde quiso ir; y así deliberó el Rey del todo la ciudad de Guadix de mano de los enemigos de nuestra santa fé cathólica, á cabo de setecientos sesenta años que había que la poseían, desde el tiempo del Rey Don Rodrigo, que la ganaron é tomaron á los christianos; é esto fué misterio de nuestro Señor, que no quiso consentir que tan noble ciudad dejase mudéjar en poder de moros más tiempo de lo pasado; é el rey fizo luego bendecir todas las mezquitas é iglesias en toda la ciudad, donde fizo luego decir misas y horas, y dió vecindades, y pobló la dicha ciudad de

14. BERNÁLDEZ, Andrés: Historia de los Reyes Católicos..., p. 639. 
Guadix de christianos, donde Jesuchristo fuese adorado como los tiempos antiguos, ante que fuese de moros, ó por ventura mejor" ${ }^{\prime 15}$.

En el verano de 1490 se dieron instrucciones al comendador de Moratalla, Diego de Soto, para que se informase de cómo estaban los caminos del Alpujarra. Se le dice que hable con don Pedro de Granada para que le presentase personas conocedoras de la situación de las vías de comunicación. Se alude al levantamiento de los vasallos del Zagal y otros mudéjares. Tras ser vencidos por los cristianos don Fernando concedió permiso a los que quisieron marcharse a Africa o a otros lugares, los que quedaron no tenían fortalezas, cercas ni fuerzas. El rey dejó guarniciones que aseguraban las tierras y controlaban a los mudéjares que permanecieron viviendo en las alquerías:

"É mandó salir đe aquellas tres cibdades é de sus arrabales, é de todas las otras villas cercadas todos los moros é moras que en ellas habían dexado por mudéxares; é dióles seguro para que pasasen si quisiesen á las partes de Africa, ó si quisiesen quedar con sus casas é bienes en sus reynos é señoríos, pudiesen morar en las aldeas é alcarías, é no entrasen en cibdad ni villa cercada"16.

El Zagal por las Capitulaciones asentadas con los Reyes Católicos había quedado como rey y señor de Andarax con las rentas de 2.000 vasallos moros que le suponían unos ingresos de 2 quentos de maravedíes. Los reyes le daban otros dos quentos hasta completar una suma considerable si tenemos en cuenta que poseía otros bienes en salinas y otras tierras. Quedó en la zona alpujarreña con sus mudéjares y todos se habían convertido en vasallos de Castilla. En 1490 en las tierras de Baza los mudéjares eran abundantes lo mismo que en Almería y Guadix. No conocemos las razones exactas que llevaron a los mudéjares a sublevarse contra el Zagal, que estuvo en varias ocasiones a punto de morir a manos de sus vasallos. Todo sucedió cuando Boabdil saliendo de Granada tomó el lugar de Alhendín. En circunstancias tan pésimas el Zagal se encaminó a Guadix para entrevistarse con el rey don Fernando, nos recuerda el cronista:

"vino a Guadix, y suplicó al Rey Don Fernando que recibiese las fortalezas que le había quedado, y cumpliese con él lo que entre ellos había quedado; é que él se quería pasar allende, que el Rey Don Fernando le diese pasaje seguro, y al Rey Don Fernando plugo mucho de esto, é cumplió con él todo lo que le había prometido, y dióle pasaje á él y á quantos moros con él quisieron ir allende; habiendo primero recibido de él, é de los alcaydes que por él estaban, todas las fortalezas, é derribado algunas no provechosas; é de esta vez se pasaron allende con el Rey Baudili Alzagal muchas casas de moros, á los quales el Rey Don Fernando permitió pasar, é pasaron seguramente, porque en los partidos había quedado, que cada e quando que el rey, ó cualquiera de los

15. Bernáldez, Andrés: Historia de los Reyes Católicos..., p. 639.

16. Pulgar, Hernando del: Crónica de los señores Reyes Católicos..., p. 509. 
moros que se dieron en su partido, se quisiesen pasar allende, que el Rey Don Fernando les diese pasaje seguro. É esto fecho, é bastecidas las fortalezas que el Rey les dió de gentes é mantenimientos, y gentes, é armas, dejando sus guarniciones donde convenía, é al Marqués de Villena por Capitán general, el rey Don Fernando, victorioso é muy honrado, se volvió á Córdoba"17\%.

Tras la sublevación quedaron en Guadix muy pocos mudéjares que se concentraron en el arrabal de la Morería y en el arrabal de la puerta de Granada. Muchos de ellos perdieron sus bienes y quedaron como jornaleros. La ciudad acordó dedicar unas tierras en el río Alhama para ellos, pero los problemas de falta de tierras para los repobladores impidieron llevar a cabo estos proyectos y los mudéjares pasaron momentos bastante críticos. La sublevación de 1490 es poco conocida aunque aluden numerosos testigos como Francisco Jabali, Cristóbal de Benavides, Francisco Leymo, Hernando Alonso, Juan Alonso, Martín Hervás y Alonso de las Casas. Todos cuentan cómo se hicieron las capitulaciones y los cargos que desempeñaron cuando servían al Zagal ${ }^{18}$.

\section{LOS MUDÉJARES DE GUADIX A PARTIR DE 1491}

Entre los mudéjares de Guadix encontramos algunos que colaboraron con los cristianos, asi se citan el Bombayre, Ali Giber, Ali Abenajara y Ali Cefin. Alguno de ellos denunció a los reyes que se apresaban a los mudéjares que salían de la ciudad hacia otros lugares. También conocemos mercedes concedidas a judíos accitanos. A partir del 9 de septiembre de 1490 se dan las instrucciones para el repartimiento de la ciudad y sus tierras. La continuidad del poblamiento estaba asegurada aunque los cambios parecían no ser tan rápidos como otros esperaban. La sublevación precipitó las cosas y la corona optó por el repartimiento al menos en los lugares donde éste tuvo mayor virulencia ${ }^{19}$. Nos dicen los testigos de estos hechos que se repartieron Guadix,

17. BERNÁLDEZ, Andrés: Historia de los Reyes Católicos..., p. 640.

18. Espinar Moreno, Manuel: «Estudios sobre las iglesias...» EsPINAR Moreno, M. y Rurz PÉreZ, R.: «Datos para el estudio de los judíos y mudéjares del Marquesado del Cenete», MEAH, XXXII, fasc. 2 ${ }^{\circ}$ Granada, 1983, pp. 113-132; Espinar Moreno, M., Ruiz Pérez, R. y Ruiz Pérez, R.: Documentos para el estudio del Marquesado del Cenete (1462-1542), Grau, Granada, 1985.

19. LADERO QueSADA, M.A.: Granada después de la conquista..., p. 4 y ss. En esta obra se estudian los repartimientos de Guadix, Fiñana, Baza, valle del Almanzora, sierra de Filabres, Vera, Mojácar, Huéscar, Vélez Blanco y Vélez Rubio, Almería, Granada y su tierra, Loja, Alhama, Vélez-Málaga, Málaga, Coín, Ronda, Marbella, y señoríos de la zona occidental. A esto hay que añadir los repartimientos estudiados últimamente que se centran en Almuñécar y su tierra y en los Montes de Granada. Cf. también ESPINAR MORENO, M.: «El agua y la tierra en Guadix desde la Baja Edad Media hasta la expulsión de los moriscos», Actas del V Centenario de la entrada en Guadix por los Reyes Católicos. Congreso de Historia, Guadix, 1990, 
Fiñana, Beas, Lares, Muñana, Gante, Graena, Lopera y Cogollos. No lo hicieron Alcudia, Cagileni, La Peza, Abla, Abrucena y Huéneja.

El 10 de septiembre de 1491 Azeite García Valle, moro, vecino del Arrabal de la Morería de Guadix, recibió una confirmación de merced de los reyes cristianos para él y sus hijos Abrahen Azeyte ${ }^{20}$, secretario del Zagal, y Alí de la Fuente, de las propiedades de Ali Arrafa y del Adalid Fadal. Estas donaciones se las dieron por ayudar a los cristianos en la revuelta de 1490 y participar en las Capitulaciones de la ciudad. Entre los bienes se nos describe una casa con su corral del Adalid Fadal, situada en el arrabal de la Morería, y los bienes de Ali Arrafa. Le entregan 20 fanegas de tierras, 2 aranzadas de huerta, dos viñas y varios morales "por quanto el dicho Arrafa está en nuestro deserviçio en las Alpujarras" 21 . Estas mercedes se las entregan al secretario de Muley Baudili o El Zagal, a su padre, a su hermano Ali de la Fuente y a sus familiares sin que tengan que pagar impuestos, eran totalmente francos por ayudar a los cristianos. El 6 de marzo de 1492 le conceden los reyes facultad para vender todos aquellos bienes. Se los vendió a Fernando de Mendoza, alcaide de Guadix, el 2 de noviembre de 1492.

En 1493 Cristóbal de Medrano, alcaide de Gorafe, expresa que Hamete Uleilas, alguacil de los moros del arrabal de Guadix "non tyene seso natural" pues cuando tenía que ordenar alguna cosa o tomar alguna resolución se reunía con los viejos y honrados y entre todos decidían lo que debía de hacerse. Su protesta era porque debían de limpiarse las acequias y el alguacil protestaba y se oponía a estos trabajos. Dice que muchos vecinos del arrabal estaban a mal con este Uleilas pues detentaba los derechos de almotacenía y alguacilazgo. Pide que le nombren otro mudéjar para que lo acompañe en todo lo que estaba realizando con los de su comunidad ${ }^{22}$.

Desde Burgos el 27 de junio de 1495 los monarcas escriben a Diego López de Trujillo, corregidor de Guadix y Almería, informándole que Hamete Uleilas, alguacil de los moros de Guadix, les había comunicado que varios vecinos de la ciudad le maltrataban y le impedían ejercer los oficios de alguacil y almotacén. Los reyes ordenan al corregidor que haga que respeten a Hamete Uleilas sus oficios ${ }^{23}$. En las Ordenanzas de Almotacenía

pp. 13-36; EsPINAR Moreno, M. y otros: «La Iglesia en la repoblación de Guadix (Siglo XV). Dotación de los Reyes Católicos», Actas del V Centenario de la entrada en Guadix por los Reyes Católicos. Congreso de Historia, Guadix, 1990, pp. 103-114; DE Miguel Rodríguez, J. C. y Segura Graiño, C.: «Notas al repartimiento de Guadix», Actas de V Centenario de la entrada en Guadix por los Reyes Católicos. Congreso de Historia, Guadix, 1990, pp. 39-44.

20. LAdero Quesada, M.A.: Los mudéjares de Castilla en tiempos de Isabel I, Valladolid, 1969, pp. 139-140. El 1 de enero de 1490 recibe exención de impuestos de pechos, derechos, alcabalas, diezmos, aduanas, almojarifazgo, etc.

21. Espinar Moreno, Manuel, Álvarez del Castillo, $\mathbf{M}^{a}$. Angustias y Guerrero lafuente, $\mathbf{M}^{a}$. Dolores: La ciudad de Guadix en los siglos XV y XVI (1490-1515), Granada, 1992, p. 54.

22. ASENJO SEdAno, Carlos: Guadix. Estudio de una ciudad mudéjar..., doc. 41.

23. LADERO QuesadA, M. A.: Los mudéjares..., doc. 66, p. 208. 
de 1495 se prohíbe echar basuras y estiércoles a las calles pues se pagarían 12 maravedies de multa entre los cristianos. De esto queda libre el barrio de los mudéjares: "Pero que en la Morería no se entienda esta ley"24. Sobre los baños del río Alhama, es decir, los de Graena, se ordena que se arreglen y que los cristianos no vean a las moras. Se pagan por utilizarlos tres blancas. Se alude además a las penas de los moros que bebían vino y quien lo hiciera pagaría 4 reales de multa y estaría en la cárcel un día y una noche. La aljama de Guadix es uno de los temas a estudiar, en este trabajo aportamos algunos documentos sobre tierras, árboles, deudas, hornos, rentas, esclavos, etc.

\section{TIERRAS Y ÁRBOLES}

El 25 de mayo de 1494 Sancho de Benavides, vecino de Guadix, arrendaba a varios mudéjares de la ciudad y de las alquerías unas tierras en el Bejarín y el Pago de Acequia. Los arrendatarios eran Axor Aboanbre, Çad Altoy y Ali el Mugrahní, vecinos de la Morería de la ciudad, y Abraydranan, Maçot Ayed, Yuça Axat y Mahoma Albiza, vecinos de Paulenca, y Mahoma de Arrobaya, Ayed Rotaya y Yuça Velcadi, vecinos de Almachar, moros. El arrendamiento era por 4 años a cambio del tercio de todo lo que cogiesen en ellas: "de todo el pan, trigo, çevada, e paniço, e lino, e de qualquier otra cosa que cogyeren en las dichas tierras, e de la paja, e de todo, forro, e linpio, puesto en las heras" 25 . Los mudéjares pondrán toda la simiente, arreglarán las acequias y realizarán los reparos necesarios sin que por ello obtuvieran beneficios. Cada uno de los años sembrarán la mitad de las tierras y la otra quedará en barbecho. Cuando acabe el arrendamiento dejarán las tierras preparadas para que el que las tomase pudiera sembrarlas. Si siembran lino pueden sacar la simiente del montón pero el tercio lo pagarían cocido y limpio.

Si los mudéjares construyen casas en el Bejarín y pasados los 4 años del arrendamiento la quieren vender lo pueden hacer. Si permanecen en el lugar les entregarán 1 fanega de tierra a cada uno para que la plante de viñedo. Si en el lugar se quedan a vivir 30 vecinos, el dueño les construirá una mezquita y los mudéjares edificarán un horno, las rentas serán destinadas al alfaquí que los atiende. Además de admitir las condiciones del contrato el que no lo cumpliera pagaría 20.000 maravedíes. Actuó de intérprete Alí Abenajara "moro, algo aljamiado".

El 29 de noviembre de 1496 Diego de la Puebla arrienda a Mahoma Xoaybi un carmen en Guadix durante dos años y le entregará de renta la mitad de todos los frutos que cogiese en la finca. Además, el arrendatario se compromete a construir y reparar las tapias del carmen durante este tiempo.

24. Asenjo Sedano, Carlos: Guadix. Estudio de una ciudad..., p. 225.

25. espinar Moreno, Manuel, Álvarez del Castillo, $\mathbf{M}^{a}$. Angustias y Guerrero Lafuente, $\mathbf{M}^{a}$. Dolores: La ciudad de Guadix en los siglos XV y XVI (1490-1515), Granada, 1992, pp. 66-68. 
En 1497 encontramos varios arrendamientos de tierras realizados por los cristianos a los mudéjares de Guadix y sus poblaciones. El 17 de marzo Cristóbal de Pancorbo entrega a Ali Mogaban, Mahoma Aladin y Ali Miliqui, moros, vecinos de Almachar, 20 marjales de viñas en término de Guadix por dos años. Le pagarán a fanales de octubre 52 reales de plata, de 32 maravedíes cada real, y 6 gallinas al año. Se comprometen a cuidar, labrar y darle las labores necesarias a las tierras y plantíos. Esta obligación la traspasó Pancorbo a Felipe Cigala porque le debía algunos dineros. Este día Farax el Mortoli tomaba a medias 12 fanegas de tierras de Diego de Herrezuelo, criado de Benito de Vitoria. La mitad de las tierras eran de Vitoria y estaban ubicadas en lo de Tiros, la otra mitad era del receptor Pedro de Cárdenas. El arrendamiento era por dos años, uno de sementera y otro de cultivo. La renta alcanza a la mitad del esquilmo. La simiente la pone el arrendatario y la saca del montón antes de la partición de la cosecha. El arrendador aporta 4 peones para la siega. El resto lo realiza el mudejar. Actuó de intérprete Ali Tagarete "aljamiado".

El último día de marzo Ayet Tixo, alguacil de Cortes, toma a renta por dos años 15 marjales de viñas en el Pago de Jerez y de Cortes. Estas eran de Lope de Araoz y las arrienda el corregidor de Guadix al mudejar. La renta alcanza la suma de 5 reales por marjal al año, pagados en octubre, y se compromete a cuidarlas, regarlas y labrarlas a vista de labradores. Actuaron de testigos el alguacil mayor Juan Pérez de Zamudio y el intérprete Ali el Toy, aljamiado. El 2 de abril el corregidor arrienda a Mahoma el Obidi un carmen en la ciudad de Guadix por un año. Este era de Lope de Araoz y le paga 1.000 maravedíes en octubre. Los intérpretes fueron Hamete Sillero y Ali el Toy.

El 28 de abril Çaçan Altoy y Muça Albexili, moros, vecinos del Arrabal de la Morería de Guadix, toman del receptor Juan Mexía dos carmenes con sus árboles y morales de Fernando de Carmona en el lugar de Baçamarin. Alrededor de los carmenes había 5 fanegas de tierras. El arrendamiento era desde abril a octubre y pagarían 6.200 maravedíes y 10 gallinas. Tras pasar este tiempo el arrendamiento se prorroga por 4 años a cambio de la misma renta. Los mudéjares tapiarán los carmenes y se les descontarán algunos gastos de la renta, sembrarán las tierras y cuidarán los árboles, se especifica "e quel dicho reçebtor sea obligado de pagar el diezmo de la fruta de comer que oviere en los dichos carmenes, e hellos de les dar las lavores que oviere menester". El intérprete es Pedro de Cárdenas.

El 4 de junio de 1497 Mahoma Quirquis y Mahoma Alcodayle, "moros, veçinos desta cibdad", arriendan de Juan de Bozmediano 5 fanegas de tierras en el Pago de Ranas. La duración del contrato es por 4 años y comienza desde el 1 de enero de 1498. La cantidad a entregar cada año es de 40 reales de plata, los entregaran a mediados de octubre. Si no pagan se les condena a entregar el doble de la cuantía. Se especifica, además, que Juan de Bozmediano se compromete a no quitarles las tierras, en caso de no cumplir ésta cláusula les 
abonaría el provecho que ellos iban a sacar de los trabajos realizados con el doble de multa. Obligaron ambas partes sus personas y bienes ante las justicias, otorgaron dos cartas para el arrendador y los arrendatarios.

El 4 de noviembre Ali Abenajara, Mahoma Bombayre y Ayed Azeyque, aljamiados, y Mahoma Damaya, Çaçan Alfeçi y Ubecar Aben Çaylón, vecinos de Guadix, tomaron a renta las tierras de regadío que tenía Rodrigo de Avalos en Alicún. Este repoblador poseía varias fincas ubicadas debajo de la Acequia Quebrada, en el pago de Turrux. Entre las condiciones del arrendamiento encontramos que sería por 4 años, aprovecharían las tierras a cambio de sembrarlas y entregarían al dueño la tercera parte de las cosechas. Rodrigo de Avalos en el primer año pone 50 fanegas de trigo como simiente. Además, se especifica que el lino y panizo para la siembra lo ponen los arrendatarios. En cuanto al trigo entregado por Rodrigo de Avalos se le devolvería tras recoger la cosecha y los mudéjares se lo llevarán hasta su casa de Guadix. Del resto de las cosechas le entregarán la tercera parte como estaba estipulado.

Los otros tres años restantes pondrían la simiente según los tercios estipulados. Se comprometen a sembrar cada año al menos 50 fanegas de trigo, si necesitan más lo comunicarán al dueño de las fincas. En este tiempo pagará el transporte de su parte Rodrigo de Avalos. Si por alguna circunstancia dejasen de sembrar alguno de los años lo harían al siguiente hasta cumplir la condición de los 4 años. Si es por negligencia de los mudéjares éstos pagarán la tercera parte. Se comprometen Ali Abenajara y sus compañeros a sembrar, curar la tierra y pagar la tercia parte cada año y entregarían el doble de lo estipulado si no cumplen estas cláusulas. Otros mudéjares llamados Mahoma Aben Çaylon, Yuça de Abençaylon, Abrayn el Marçeli, Ali Melique y Mahoma de Xaudari se obligan junto con los anteriores a que todo aquello se cumpliera. Por su parte Rodrigo de Avalos se compromete a respetar todas aquellas condiciones, entregará la simiente cada año y no se las quitará, si lo hace les pagará el doble. Actuaron de testigos Alonso de Castro, el intérprete Sancho de Alarcón, Alonso de Morales y Juan Continente, vecino de Baza.

El 1 de diciembre Diego López de Tejada arrienda a Zufari, moro, algo aljamiado, 7 fanegas de tierras en el Pago de Fabinar por dos años "para que las barbeche ogaño e las sienbre otro". Le pagará a cambio de cinco partes de la cosecha dos para el dueño y tres quedarán para Zufari. Todo estará limpio y puesto en las eras antes de la partición. Diego López pone dos partes de la simiente, arregla y conserva limpia el acequia. Por su parte el mudéjar aporta tres partes de la simiente y pone el trabajo de la siega, trilla, limpia, etc., hasta poner la cosecha en momento de partirla entre ambos. Se redactaron dos cartas de arrendamiento para cada uno la suya.

El 2 de diciembre el vicario Pedro Hervás en su nombre y en el de la Iglesia arrendó por cuatro años unos carmenes en el camino del Ciguení a Abrahan Albacar y a Mahoma Alpujarri, moros. Estaban junto a unos mo- 
rales de la Iglesia y la Acequia de la Ciudad. Le pagarían 1.240 maravedies, 4 gallinas "buenas, bibas"y 1'5 fanegas de castañas a finales de octubre de cada año. Los mudéjares se obligan a labrar, cavar los árboles, podar las cepas y realizar cuantos trabajos fuesen necesarios para mantener bien aquellas propiedades.

El 3 de diciembre Gutierre Gaytán entrega a renta otro carmen a Ali Xav y a Mahoma Dalfaquí por 26 reales de 34 maravedíes al año, pagados a finales de octubre. El mudéjar Ali Xav es el arrendatario principal y el otro su fiador. Se encontraba el carmen junto al de Fernando del Castillo y el de Alonso Alférez. Se comprometen los moros a plantar parras, cavar los árboles, cuidar el carmen y labrar las tierras a vista de labradores.

El 11 de diciembre el contador Francisco Martínez arrienda al moro Hamete Rami un soto en Luchena para que rompiera las tierras y las pusiese en cultivo. El arrendamiento es por cuatro años. En el primero gozaría el Rami y otros que le ayudasen de todo lo que sembrasen sin pagar renta ninguna. Los tres años restantes entregará el tercio, limpio y puesto en su casa de Luchena. La simiente la aporta el Rami y los otros durante todo el tiempo del arrendamiento y la recuperarán en la era. Hizo de intérprete de este contrato Hamete Sillero. Este mismo día Manuel de Ubeda arrienda a Hamete Abenmote, moro, 1'5 aranzadas de viñas en el Pago de Jerez por diez años a cambio de 35 reales, de 34 maravedíes, y 2 gallinas entregadas a finales de octubre de cada anualidad. Se compromete el moro a cavarlas, binarlas, regarlas y labrarlas. El intérprete fue Mahomad, pastor de Abenajara.

También este día Juan de Bozmediano da a renta a Ali Benajara, moro, algo aljamiado, 24 fanegas de tierras en el Pago de Polera. Diez junto a las de Fernando de Córdoba y Juan de Cárdenas, y las 14 restantes en la Rambla de Deosal junto a las de Carrillo. El arrendamiento es por 4 años a cambio de 1'5 fanegas de trigo y media fanega de cebada por cada fanega sembrada, es decir, 36 fanegas de trigo, 12 de cebada y 14 gallinas que se entregarán en su casa de la ciudad a finales de agosto de cada año. Ali Benajara pagará el diezmo de las cosechas. Hicieron dos cartas con todas las condiciones del arrendamiento. Este mismo propietario arrendaba este día otras 10 fanegas a Ali Benajara en Graena en el río Alhama por el mismo tiempo que las anteriores. Le entregará 1.600 maravedíes al año a finales de octubre. Más otras 5 fanegas en Cortes por 620 maravedies y 10 gallinas.

El 12 de diciembre Pedro de Arévalo da a renta a Mahoma de Axergali, Ali Mayd, Hamete Lagara y Mahoma Alcujari, moros, vecinos de Guadix, "todos algo aljamiados", un carmen con 24 marjales de tierras en el Chiribayle junto a las fincas de Mino, de Pedro Mateo y el acequia. Se lo da por cuatro años y 1.200 maravedíes pagados en octubre. Cuidarán las tierras y el carmen además de otras labores necesarias.

El 15 de diciembre Juan de Aranda da a Ali Garbal "algo aljamiado", vecino de Paulenca, un carmen y 9 fanegas de tierras y dos cármenes de 
viñas en el camino de Paulenca linderos de fincas de Pedro de la peña y viñas de Bezerril. Se las da por dos años a cambio de que las cuide y labre encomendándole lo siguiente: "Para que cure e labre los árboles, e carmen, e viña, e barbeche las tierras de las labores que oviere menester, a vista de labradores". Partirán por medio la cosecha cuando ésta esté limpia y preparada para la partición. El mudéjar pone la simiente y la recupera antes de partir. Actúa de intérprete Ali Gazi, alguacil de Cogollos.

Este día Fernando de Barcena, vecino de Guadix, arrienda a Hamete Albuchichi y a Abdala Merin, moros, algo aljamiados, 1'5 aranzadas de viñas en Paulenca, linderas a las de Juan de Salas y las de Pancorbo. Las da por dos años a cambio de 28 reales de 34 maravedíes que pagan a finales de octubre. Las cavará, binará, regará y dará todas las labores necesarias destacanto al menos que debe de "amigronar e hechar migrones donde fuere menester, e curarlas a vista de labradores".

Cristóbal de Montoya arrendó a Mahoma Barraba, vecino de Guadix, "algo aljamiado", a Hamete Çaniya y Ali el Beaxi, moros, vecinos de Graena, una aranzada de viñas en el Pago del Castillejo durante dos años por 14 reales de 31 maravedíes pagados a finales de octubre. Hizo de intérprete el alguacil Juan Pérez de Zamudio. El 17 de diciembre Bartolomé de Ayala arrienda a Mahoma Guadixi, moro, una casa con un carmen que estaba junto a la de Gómez de la Cámara, la de Bacares y la de Juan de Biedma, el arrendamiento es por dos años y le pagará 1.800 maravedíes además de cuidar el carmen y la vivienda.

El 21 de diciembre de 1497 Rodrigo de Avalos realiza varios arrendamientos de tierras en el Pago de Almunia. El primero lo hace con Hamete Alpartal, moro, con una haza de 6 marjales que estaban junto a propiedades de Alonso de Avila, del contador Gómez de la Cámara y una rambla. El arrendamiento era por tres años, pagaba 68 maravedíes por marjal alcanzando la cantidad de 408 maravedies que le entregaba a primeros de octubre. El segundo arrendamiento fue a Hamete el Marceli con una haza de 7 marjales junto a los mismos linderos, la cantidad total era de 466 maravedíes. El tercero a favor de Çad Alfobil con otros 7 marjales y con las mismas condiciones que los anteriores. El intérprete de los tres contratos fue Pedro Sangilero.

El 25 de marzo de 1498 Juan Daroca arrienda a Abrayn Alhamexi, moro, aljamiado, dos cuartas de viña en el Chiribayle que estaban junto a las de Bartolomé de la Vicaría y de Martín Sánchez, hortelano. Se las dio por cuatro años especificando en el contrato que los dos primeros las cuidará y labrará gozando del esquilmo. El resto del tiempo le entregará de renta la mitad de la cosecha. El 4 de junio Juan Daroca le entregó tres bancales y una viña pequeña a Abrayn Gracioso sin que le entregase nada de renta para que la cuidase y labrase.

Entre otros contratos se nos cita otro de 7 de mayo por el que Alonso de Guzmán arrienda a Mahoma Rami, aljamiado, la hoja de 40 morales en el 
Pago de la Rambla de Fiñana. Estos lindaban con otros de Sancho de Benavides y el acequia del lugar. Se los dio por un año "para que los coxa bien coxidos" a cambio de 17 reales nuevos cuando saque los capullos. El 9 de mayo Francisco Arias da a censo a Hamete Abentofayle, moro, vecino de Ciguení, una haza de dos fanegas de sembradura en el Pago de Centenares, con 13 morales y otros árboles. Lindaban con tierras de Çaçan Alcabri y de Çaçan Açumayda. Le entregó también un marjal de viña y algunos árboles. El censo perpetuo era por 510 maravedíes al año y se los entregará el primer día de octubre. No podrá vender el censo a la Iglesia, ni a monasterio, ni caballero, y debe tener licencia del dueño. Si no paga durante dos años pierde el censo. Le da otro censo a Mahomad el Balori este día, es de tres morales "en que avía doze pies de morales, poco más o menos". Este censo era por cuatro años y le pagaba 360 maravedíes al año a primero de octubre. Hizo de intérprete en ambos censos Ali el Toy, moro.

El 11 de mayo Pedro Mateo arrienda a Ali Alarife, moro, 12 marjales en el Pago de Luchena junto a las de Luis de Madrid y unas torrenteras. El arrendamiento era por ocho años y le pagaba 306 maravedíes al año a finales de octubre. El intérprete fue el sastre Fernando de Jaén. El 19 de mayo Gonzalo Núñez da a censo perpetuo a Hamete Albaysi, moro, algo aljamiado, y a Yça el Marçeli, moro, una moraleda con 28 morales en el pago de Çuchar junto al camino de Alcudia, encima del acequia de Almeçin. Le entregarán 930 maravedíes y 2 gallinas a finales de octubre de cada año. El censo era de por vida de ellos y de sus hijos y herederos. El intérprete fue Rodrigo de Baeza, hijo de Gonzalo de Baeza. En 1499 este censo pasó de Gonzalo Núñez a Jacome Gentil por una deuda de unos paños. El 22 de mayo Fernando del Castillo, hermano del merino, arrienda a Mahoma Rami, moro, aljamiado, un carmen en el camino de Baza junto al del merino Castillo. El tiempo era de un año a cambio de la fruta y la hoja de los morales más 485 maravedíes y 4 gallinas que entregará a finales de octubre.

El 10 de junio el tornadizo Marco Marín e Isabel Hernández venden a Sancho de Benavides 4 morales junto a tierras de Rincón y Juan de Cortinas en Cogollos. El precio fue de 902 maravedíes. El 18 de junio Juan Falcón da a censo perpetuo a Mahoma el Biçan, moro, media aranzada de viña con un castaño y otros árboles en el Pago de Centenares. Los linderos eran morales de Carrillo, propiedades de Francisco Arias y viñas del Ciguení. Le entregará 300 maravedies a finales de octubre. El intérprete fue Hamete Sillero.

El 29 de enero de 1499 Benito de Vitoria arrienda a Alí Tixo, moro, alguacil de Cortes, la alquería de Almidar con todas las tierras que le pertenecían. El arrendamiento se hizo por 10 años. Durante este tiempo se aprovecha del esquilmo y paga de renta el tercio de las cosechas, pan, paja y otras cosas que llevará hasta la casa de Vitoria en Almidar. De todas las tierras cedidas en arrendamiento se sacarán las que necesiten dos pares de bueyes, las entregaría al Hodrí y a Alhadua, moros, como les correspondiese por suerte, 
así se había hecho con otros que ya estaban trabajando las tierras. Estos dos moros entregan a Vitoria la mitad de todo lo que cogieren en la casa de Almidar. Benito de Vitoria pone el tercio de la simiente y los otros moros los dos tercios. Por el contrario se especifica en una de las condiciones del contrato que si alguna acequia rompiera el río o se construyese de nuevo pondría Vitoria dos partes y Ali Tixo una. Costearía Vitoria, además, un corral con su tinada para encerrar los ganados y Ali Tixo y los otros mudéjares tendrán que llevar atocha y otros materiales para conseguir estiércol suficiente para estercolar las tierras, especialmente se especifica "por manera que aya estiércol para estercolar la faça de Almituyd para que syenbre cada año". El resto estará un año sembrado y el otro en barbecho. Actuó de intérprete Hamete Sillero, moro, aljamiado.

El 3 de febrero Francisco Arias y Ali Yaçan, moro, aljamiado, cambian algunos bienes. El mudéjar da 1 marjal en el Camino del Ciguení a cambio de otro marjal en el mismo lugar más dos reales de censo. El 11 de febrero Fernando de Aranda arrienda a Abrayn Ambre, moro, dos pedazos de viñas con 3 marjales en el Pago de Alhamarín, estaban junto a las tierras de Fernando de Carmona y las de Pedro de Ribera. El arrendamiento es por cuatro años y le da de renta la mitad de la cosecha que obtenga de las viñas al tiempo de la cosecha. Se especifica en el contrato "Es condiçión que las a de cavar, e vinar, e regar, e dar las labores que fueren menester a vista de labradores, so pena que sy alguna labor le dexare de dar e algo de esquilmo se perdiere, que sea obligado a gelo pagar con el doblo". El mudéjar puede tomar de un marjal todas las uvas que quisiese para el consumo de su casa sin que cuenten en la partición. Hizo de intérprete Mahoma de Aborrida. Este día Alonso Alférez, vecino de Guadix, arrendó un carmen a Hamid Mizcalán, moro. Estaba el carmen junto a los de Gonzalo de Cortinas. El arrendamiento era hasta finales de octubre y le paga 680 maravedíes teniendo que cuidarlo. El intérprete de este contrato fue Rodrigo de Baeza, hijo de Gonzalo de Baeza.

El 19 de febrero entraron a trabajar para Gonzalo Núñez el cristiano nuevo, Pedro, y Martín, hijo de Alonso de Salamanca, durante un mes, tendrían que cavar las viñas, labrarlas y escardarlas en Albuñan o en otros sitios donde los mandase y hacer otras tareas "que honesto fuese de faser". Recibirán dos ducados de oro y una fanega de trigo por todo el tiempo de soldada, más un azumbre de vino diario. El dinero lo recibirán en cuatro pagas como les correspondiese.

El 28 de febrero el clérigo Juan de San Pedro, en nombre del obispo de Guadix, arrienda a Hamete Huxeyas, como principal, y a Çayde, tendero, como su fiador, un carmen del obispo en el Arrabal de la Morería por dos años. La renta anual es de 32 reales nuevos "de a treynta e quatro maravedís cada uno", dos gallinas y el fruto de uno de los perales del carmen que escogiere Juan de San Pedro o el señor obispo de Guadix. Pagarían a finales de 
octubre de cada año. Se especifica en el contrato que los arrendatarios mantendrían el carmen en buen estado: " e más, que en cada uno de los dichos dos años, ellos texarán, e repararán, e adobarán la casa del dicho carmen a su costa, dándoles el dicho Juan de San Pedro todos los materiales de madera, e texa, e cal, e las otras que oviere menester, e que los maestros, e peones, e adobo de la dicha casa a su costa, e obligaronse de cunplir lo suso dicho, e de no le dexar, so pena de pagar el dicho arrendamiento con el doblo".

El 18 de marzo Pedro de Cuéllar vendió a Pedro Sangilero y a su esposa María de Sazedo 4 morales en el río Alhama, en la cuadrilla de Juan Dorgas, por 204 maravedíes. El 22 de marzo Cristóbal de Pancorbo arrendó a Ali Benajara la hoja de 20 morales encima del Ciguení que eran de Luis de Mexía. El arrendamiento fue de un año para que gozase de la hoja de ellos, entregará 720 maravedíes y una gallina que pagará por San Juan de junio.

El 24 de abril el alcaide de la villa de La Peza, Bartolomé de Mérida, vendió al alguacil Alí Lipuri media fanega de tierra en el pago de Alhalaque, lindera con tierras de Mahoma de Romaque, viña del alguacil y de Alizar Lipuri. El precio fue de 900 maravedíes.

El 1 de mayo Gonzalo Núñez vendió a Çaçan el Cambile, moro, vecino de Guadix, unas tierras por 225 miscales de a 30 maravedíes cada uno. Se comprometió en entregarlos a finales de octubre del 1500. El mudéjar había pedido los 225 miscales a Jacome Gentil y se los entregó a cambio de unos paños y seda. La carta de pago la dará Núñez a Jacome y a Çaçan. Se comprometieron todos ante las justicias a atenerse a las leyes.

El 8 de mayo Hamete Sillero, moro, aljamiado, en nombre de otros mudéjares expone que la ciudad de Guadix y su procurador sacaron algunas prendas a unos moros de Graena porque debían 18 fanegas de cebada por el terrazgo de unas tierras en el río Alhama del año 1498. Ante la petición de Hamete Sillero se devolvieron las prendas tomadas. Se compromete en nombre de ellos a pagar lo estipulado por el procurador de Guadix más las costas.

El 9 de mayo Cristóbal de Pancorbo arrienda a Mahoma de Abenzaylón, moro, aljamiado, un carmen en el camino del molino de Juan de Almaraz, alinda con tierras de Pancorbo. El carmen es arrendado con su casa y árboles durante dos años por 510 maravedies y una gallina al año, pagados a finales de octubre. Se compromete a labrar, curar, adobar y cavar las tierras y viñas "e de le adobar la casa, e tapiar la huerta, contando que sy por su cabsa del dicho Abenzaylon se cayere, que sea obligado a lo pagar, e adobar a su costa". El dueño se compromete a no quitarle el carmen durante aquel tiempo.

El 2 de agosto de 1499 el alcaide de la Alcazaba de Guadix, don Fernando de Mendoza, arrienda 30 marjales de tierras a Haburrida y a Hamete Algorabí, moros, vecinos de la ciudad. Las tierras estaban en la Rambla de Fiñana y tenían como linderos tierras de Bazán, Diego de la 
Cueva y una rambla. El tiempo era de cuatro años por 75 maravedíes cada marjal y tres gallinas al año en el mes de agosto. Además les dio una noguera en las tierras "para que gozen del esquilmo". Ambas partes se comprometen a cumplir lo estipulado en el contrato. Actuaron de testigos Gonzalo de Baeza, Bartolomé de Teruel y de intérprete Abrayn Albucar, moro aljamiado. El 21 de agosto en la venta de una viña encontramos como lindero de esta propiedad a Abrayn Azeyte, en el río Alhama.

El 24 de agosto Gonzalo Arias se traslada a la corte de los Reyes Católicos porque le donaron 10 caballerías de tierras en Guadix y más tarde se las habían quitado. Tras examinar el caso se acordó pagarle la cantidad de 71.500 maravedíes de las rentas de sus altezas. Los reyes ordenaron al regidor de Guadix, Benito de Vitoria, que le pagase. Este, a su vez, ordenó que se los diesen de ciertas rentas y tributos de moros de la ciudad de Vera. Gonzalo Arias da poderes a Bernaldino de Pinar para recibir aquella cantidad. Los obtuvo de los bienes de mudéjares y de los moros que se vendieron en almoneda pública. Tras cobrarlos se le pidió carta de pago de todo lo que recibe para conocimiento de Benito de Vitoria y de los monarcas.

El 26 de agosto Domingo de Aragón tomó a soldada a Pedro de Guadix, cristiano nuevo, por tiempo de dos meses para que le ayudase a cuidar las viñas de la Rambla de Fiñana. Le paga 238 maravedíes por los dos meses. Pedro de Guadix se compromete a cumplir con el trabajo a cambio de la comida, bebida y el dinero de su jornal.

El 15 de septiembre Ali Benajara, moro, vecino de Guadix, concede poderes a Ali el Buyre, moro, vecino de Cogollos, para que pueda arrendar toda o parte de la hacienda del marqués de Villena. Se compromete a aceptar lo que hiciera el dicho Buyre en su nombre.

El 27 de septiembre Gonzalo Núñez vende a Ayed Çafin, moro, vecino de Guadix, tres hazas con 2'5 fanegas de sembradura. Estaban en Graena junto a tierras de Çafan, de Núñez, de Juan de Almares y de Fernando de Aranda. El precio fue de 2.000 maravedíes. Especifican en la carta que si había más tierra pagaría al respecto y si menos el vendedor devolvería la cantidad correspondiente. Actuó de intérprete Hamete Sillero.

El 29 de septiembre Ali Abençayre, hijo de Aduladin, moro, vecino de Guadix, arrendó a Ali el Vayre y Abrayn Algaraxi, moros, vecinos de Cogollos, 25 fanegas de tierras en el Pago del Toberal, alinde de propiedades de Francisco Pérez. Además, les arrienda otras 20 fanegas en Lugros junto a las de Ordas. El arrendamiento era por cuatro años; los dos primeros, de simiente, y los otros dos, de barbecho. Los moros gozan de los esquilmos. De las 25 fanegas entregan la tercera parte, libre, "horro", y de las 20 fanegas de Lugros pagan el cuarto, libre, puesto en las eras. Los arrendatarios ponen la simiente y la recuperan al sacar la cosecha.

El 4 de octubre de 1499 el receptor Juan Mexía arrienda a Mahoma Albenxi, moro, vecino de Guadix, una huerta dentro de la ciudad junto a 
otras de Mexía y de Manuel de Cortinas. El arrendamiento es por tres años para que se aproveche de ella y de los esquilmos a cambio de una renta de 35 reales nuevos "de a treynta e quatro maravedís cada uno" y 4 gallinas que entrega a finales de octubre de cada año. Especifican que si algo se cae en la huerta lo obraría y repararía Abenxi a cuenta de la renta. Se comprometen ambas partes a cumplir lo estipulado y a pagar los daños ocasionados. Hizo de intérprete Mahoma Romayne, vecino de Guadix. También este día Fernando de Medina arrienda a Abrayn Albuyre, moro, vecino de Paulenca, una haza de 6 fanegas en Graena junto a las propiedades de Diego de Ordaz y una rambla. El arrendamiento es por cuatro años. El arrendatario pone la simiente y la toma del montón. De lo que quede le entrega la tercera parte, libre, limpio y puesta en su casa, más dos cargas de paja. Abrayn se compromete a hacer todo y paga "al tienpo del coxer el pan, so pena del doblo". Hizo de intérprete Yaya Sillero.

El 5 de octubre de 1499 don Fernando de Mendoza, alcaide de la Alcazaba de Guadix, arrienda a Abrayn Xuabi, moro, vecino de la ciudad, una huerta en Guadix junto a un carmen de Cortezo, el horno de los moros, huertas de Gálvez y de Luis González. Se la entregaba con unas cuevas y árboles durante cuatro años para que se aproveche de la huerta y de los esquilmos que sacase de ella. La renta es de 1.000 maravedíes y 6 gallinas al año a primeros de octubre. Esta huerta nos dice el escribano que era un carmen, debían de labrarlo, curarlo y repararlo en todo lo que fuera menester. $\mathrm{El}$ intérprete fue Yaya Sillero, vecino de Guadix.

El 6 de octubre Alonso de Mohidas dio a censo perpetuo a Mahoma de Abenbaco, moro, aljamiado, vecino de Alcudia, 5 morales en la villa junto a corrales de Pedro Díaz de Navarrete por el precio de 8 reales nuevos, de 34 maravedíes, por Santa María de agosto de cada año. Estos morales no los puede vender a la iglesia sin el permiso del dueño, si lo hace los tributos serán de Mohidas y si no paga en dos años perderá los derechos del censo. El intérprete fue Mateo Tetagarete.

El 28 de octubre Lope de Zarate, criado de Fernando Sánchez de Zafra, por un poder que tenía arrienda a Hamete Azeytuni, moro, vecino del Arrabal de Guadix, 18 fanegas de tierras en el Pago de Luchena, junto a tierras de Luis de Méndez y del merino Castillo. El arrendamiento fue por cuatro años a cambio de pagar 16 fanegas y 8 celemines de pan: "la mitad trigo y la mitad çebada, e mas syete reales nuevos, de a treynta e quatro maravedís, e dos gallinas" al año a finales de octubre. El intérprete fue Asensio de Santacruz. El 31 de octubre el mismo Lope de Zarate arrienda a Hamete Sillero, moro, vecino de Guadix, 2'5 aranzadas de viñas en el Pago de Façad Garraf. Se las arrienda por 10 años "e los dos años primeros las cabe, e labre, e riegue, e cure, e que por lo que en ello gastare goze del dicho esquilmo, e no pague renta ninguna". Los otros ocho años le entregará dos ducados de oro o su justo valor a finales de octubre. Se compromete el arrendatario a 
poner los mogrones de la viña que faitaren además a labrar y curar la viña "a vista de labradores", sobre todo amogronará las cepas y las cuidará.

El 13 de diciembre Pedro de Illescas arrienda a Bulgayre, negro, aljamiado, vecino de Guadix, 4 marjales de tierras en el Pago de Chitrana, alindando con tierras de Sancho de Benavides, por tiempo de cuatro años por el precio de 68 maravedíes el marjal, en total 272 maravedíes y una gallina, a finales de octubre de cada año. Si decide venderlas debe de ser el arrendatario el que las compre o esperar a que transcurra el tiempo del arrendamiento. Entre los testigos de esta carta encontramos a Fernando de Andrada, Antonio de San Martín y Mahoma Benalfaqui.

El 20 de diciembre de 1499 Francisco de Bolaños arrendó a Ali Baqui, Aborrida, Çaçan Alfeçi y a Mahoma de Abrama, moros, vecinos de la ciudad 14 marjales de tierras en el Pago de Façad Garraf, alindaban con tierras de Manuel de Cortinas. Cada uno de ellos obtuvo una parte de estas tierras, asi Ali Baqui cinco marjales, a Aborrida tres marjales, a Çaçan Elfeçi tres marjales y a Mahoma de Abrama otros tres marjales. A todos ellos se los arrendó durante cuatro años para que gozasen de las tierras a cambio de entregarle 170 maravedís y media gallina por marjal, pagados a primeros de octubre de cada año. Cada uno pagará al respecto de lo que arrienda. Actuó de intérprete Felipe Cigala, genovés, y de testigo Abdalla Bedadin, aljamiado.

E1 31 de diciembre Pedro Sangilero arrienda a Mahoma Castali, moro, aljamiado, vecino de Cortes, 12 fanegas de tierras en el pago de Cortes, alindaban con fincas de Francisco de Bolaños. Se las da por dos años para que las siembre de cebada y panizo. Cuando saque el esquilmo descuenta la simiente y del resto de las cosechas le dan la mitad, limpio y puesto en las eras, excepto la paja que será entera para Castali. Le entrega todo conforme a lo estipulado y si no le costará el doble.

El 7 de enero del 1500 otorgó Alonso de Mohidas, vecino de Guadix, que arrendaba a Maçote Abençafy, Maçote Aly Aynid y Mahomad Manax, moros, vecinos de la ciudad, 16 fanegas de tierras en el Pago de Tiris, alindan con tierras de Fernando de Medina, de Fernando de Torres y el camino. Se las arrendó por 10 años. Le pagan sólo los cinco últimos años cada uno de ellos 20 fanegas de trigo, 20 de cebada y 4 cargas de paja, puesto todo en su casa a costa de los moros a finales de agosto de cada año. Los mudéjares se comprometen a cumplir las condiciones del contrato. Actuó de intérprete Hamete Sillero.

El 17 de abril el clérigo Diego Fernández da a censo perpetuo a Yuça Polera, vecino de Almachar, tres marjales de viñas en el Pago de Almachar que estaban junto a las de Alonso de Baeza. Se las entrega con la condición que "en este tienpo las labre, e cabe, e riegue, e de las otras labores que oviere menester a vista de maestros, e goze del esquilmo dellas". La renta es de 480 maravedíes pagados a finales de cada año. Si deja de cuidarlas, intenta venderlas o no paga durante dos años las perderá. 
El 24 de julio Francisco Arias, en nombre de Diego de Aldrete y por el poder que le concedió, arrienda a Mahoma Gali, moro, una haza de $7^{\prime} 5$ marjales en el Pago de Galicante. El arrendamiento es por cuatro años y paga 575 maravedíes a primero de octubre. El intérprete fue Mahoma de Uleylas. El 11 de agosto Gómez de Aponte arrienda a Muça Bexer y a Mahoma Bexer, moros, hermanos, cuatro fanegas de tierras en el molino del Cardenal junto a las de Fernando de Illescas y las de Montalvo. Las entrega por cuatro años a cambio de 24 reales nuevos que suman 816 maravedíes al año. La mitad de la renta la entregan en san Juan y el resto a finales de año. El intérprete fue Hamete Albaçea.

El 18 de octubre del 1500 Fernando del Castillo arrienda al cristiano nuevo Diego Tamarite, antes Aly Tamarite, un carmen en Guadix junto a los del receptor Juan Mexía, el de Aranda y el río. Se lo da por cuatro años "para que en este tienpo lo labre, e cure, e se aproveche, e de fruto, e esquilmo del". La renta anual es de 750 maravedíes, dos gallinas y un pollo que entrega en tercios a lo largo del año. Se comprometen a cumplir con las condiciones del contrato y el arrendatario dice que lo tendrá "reparado, a lo menos como agora lo resçibe, so pena de pagar la dicha renta con el doblo, etc". Se redactaron dos cartas "de un tenor para cada parte la suya". El intérprete fue Diego Herrezuelo.

El 27 de octubre Alonso Navarrete arrienda al cristiano nuevo Fernando Alonso, antes Mahoma Alçujarí, una huerta en el camino del Cenete en la acequia de la Ciudad, alinda con huerta de Francisco de Vera. Le da todos los árboles y un pedazo de viña que estaba dentro de la huerta. El arrendamiento es por dos años y debe de renta 748 maravedíes que los entrega a finales de octubre de cada año. Entre las condiciones se dice que labrará, curará, regará y realizará todas las labores necesarias a su costa. En cuanto a la viña el dueño pone la mitad de los peones "que entraren en el cabar la viña". Al día siguiente Diego López Benajara, cristiano nuevo, antes Ali Benajara, arrienda a Lope del Royo, antes Abrayn Alhamar, y a Juan de Luna, antes Mahoma Çarco, un carmen de pertenecía al marqués de Villena en término de Guadix. Los linderos eran otros carmenes. Se lo arrienda con casas, árboles y morales "e con todo lo otro questá en el dicho carmen". Lo cede durante un año por 4.000 maravedíes que recibirá en dos pagas, una a finales de agosto y, la otra, a finales de octubre. Cuidarán las tierras y repararán las casas y tapias de la huerta. Si se originan gastos éstos se descuentan de la renta pero lo comunicarán a Benajara para que se lo reciba a cuenta. Ellos por su parte se comprometen a "lo curar, e cabar, e regar, e adereçar a su costa, e en lo que ovieren de reparar en las casas, e tapias, e otros reparos que convengan, que los harán a costa de la dicha renta, e lo harán saber al dicho Diego Lópes, que gelo resçibirá en cuenta".

El miércoles 4 de noviembre María López, esposa de Fernando de Gálvez, arrienda al cristiano nuevo Fernando, antes llamado Fernando Dinar, una huerta junto a la acequia de la Ciudad, huerta de Bolaños y el 
camino. En el contrato se especifica que entraban los árboles y paga de renta 45 reales nuevos a finales del año. El arrendatario tiene que labrarla, curarla y aderezarla "a vista de veedores, como buenos carmenes deben estar". Las casas, huerta y tapias deben repararse y los gastos ocasionados de descuentan de la renta siempre que lo comunique al dueño.

El 12 de noviembre Isabel Fernández, esposa de Fernando Marín, arrienda a Juan de Benavides, antes Abrayn Juay, y a Sebastián de Guadix, antes Arcan, vecinos de la ciudad, doce fanegas de tierras en el camino de Jaén, debajo de la acequia de Lupe y de Rapales. Las entrega por cuatro años a cambio de 95 pesantes, de 30 maravedíes, que suman 2.850 maravedíes, dos gallinas y una carga de paja pagados a finales de octubre. Al día siguiente el cristiano nuevo Francisco Ortega vende a Gonzalo de Aponte una haza de cuatro celemines y un bancal de viña en Paulenca que estaba junto a otras tierras de Aponte, de Juan de Sosa y huerta de Moratalla. Le entregaron por la tierra y los árboles 440 maravedíes.

El 15 de noviembre García de Arana arrienda a Juan de Guadix, antes Moharib, 20 fanegas de tierras en el Pago de Bexarín, junto a las de Sancho de Benavides. Se las dio por cuatro años, dos de sembrado y dos de barbecho. Le paga el tercio de lo que cogiere puesto en las eras. Además le da otras 20 fanegas en Pocullar con las mismas condiciones, junto a las de Diego de Barrionuevo, de Fernando de Medina y de Andrada. Paga la mitad de lo que cogiese y Juan de Guadix pone la simiente para recuperarla antes de la partición de la cosecha.

El 24 de diciembre Antonio de Rabaneda entrega una huerta a unos moriscos de la ciudad, estos eran Diego de Guadix, antes Ali Çaba, su esposa María, antes Axa, a Alonso de Guadix, antes Çad Çaba, y a Catalina, su mujer, antes Axa, y a Fernando, antes Fernando el Gazene. La huerta era del marqués del Cenete, con unos bancales de tierra que estaban junto a ella. Se lo arrienda por un año a cambio de 160 pesantes, de 30 maravedíes cada uno, que suman 4.800 maravedíes. Le pagan en tercios cada año lo que corresponda. Le entregan, además, una fanega de castañas y otra de nueces en el tiempo de la cosecha o el precio de ellas. Los manzanos de invierno serán para el dicho Rabaneda. Los arrendatarios se comprometen a cumplir todas aquellas condiciones y a pagar los 160 miscales, de a treinta maravedíes cada uno, a los tercios establecidos, de lo contrario entregarán el doble del total de la renta.

No sabemos la fecha de un arrendamiento realizado por el licenciado Diego López de Trugillo, corregidor de la ciudad, que en nombre de Lope de Araoz, secretario del comendador, entregaba algunos bienes a Ayed Tijo, alguacil de Cortes, y a Mahoma Castaño, aljamiado, moro, de Cortes. En total 16 marjales de viñas en el Pago de Beas. Las arrienda por cuatro a cambio de renta 155 maravedíes por marjal, pagados cuando cogiesen el esquilmo y frutos de ellas. Las podarán, cavarán, labrarán y regarán a vista de labradores. Actuó de interprete del alguacil el dicho Mahoma Castaño. 


\section{PODERES}

Los mudéjares accitanos conceden poderes a los cristianos para que los defiendan en pleitos y otras causas. También se representan entre ellos cuando al que le ceden tales prerrogativas habla castellano. Sobre todo los poderes se ceden cuando el musulmán tiene alguna acción legal con un cristiano pues entonces son juzgados por las justicias castellanas.

El 21 de noviembre de 1496 Ali Tixo, alguacil de Cortes, y Ali Belchite o Belite, alguacil de Graena, dan poderes a Rui Díaz de Tamayo para que los represente en lo jurídico y en las deudas que puedan tener. Sabemos que debía de cobrar para estos mudéjares 3.050 maravedíes de los herederos de maestre Francisco "que le dieron por mandado de la çibdad, e no los avía de aver".

En diciembre Pedro de Aranda da poderes a Bartolomé de Aranda, que estaba ausente, para que pueda representarlo en juicio. Se obligó de acatar todo lo que hiciese en su nombre. El 22 de diciembre de 1496 Lope Sánchez Trompeta concede poderes a Luis de Tamayo, escribano de mozos, para que lo represente en todo, revoca cualquier acción que fuese en contrario de este poder.

Muchos de los mudéjares no sabían nada de castellano y por ello entregaban poderes a otros de su comunidad o a vecinos cristianos. El 1 de abril de 1497 Ayet Tixo, alguacil de Cortes, concede poderes a Gonzalo de Baeza para que lo represente en juicio y cobre en su nombre de los herederos de mestre Francisco Sefisico una cantidad que le debía. Hizo de intérprete del contrato Hemete Sillero. El 31 de diciembre Mahamad Abenamar, moro, "por lengua de Pedro de Cárdenas" concede poderes a Alonso Ruiz, armero, para que lo represente en los pleitos y sobre todo para que reclame un buey "que le mataron en la carneçería".

El 15 de junio de 1498 Mahoma Cortezo y Mahoma Xuabi, moros, dan poderes a Gonzalo de Baeza para que demande y cobre de Yuça Navarro una cantidad de cebada por una haza que le dieron.

Hamete de Uleylas da poderes a Hamete Sillero y a Mahoma Benalfiqui, moros, aljamiados, para que en su nombre puedan entender en los oficios de alguacil y almotacén de los mudéjares de Guadix y su tierra. Pueden realizar cuantas acciones crean oportunas siempre que ejerzan estos oficios de acuerdo a lo estipulado por los reyes. Se obliga ante las justicias Uleylas a aceptar todo lo que hiciesen en su nombre.

El 9 de febrero de 1499 Luis de Acuña, vecino de Zújar, da poderes a su hijo Fernando de Acuña para que cobre de Pedro de Guadix, cristiano nuevo, 240 maravedíes de una cuenta y otros 65 pesantes, de 30 maravedíes, de Mahoma de Lupe según se especificaba en una carta de obligación escrita en árabe. Le dice que les dé cartas de pago cuando salden sus deudas. El 1 de marzo Maçote el Cabri da poderes a Gonzalo de Baeza para que cobre 
de Ali el Toy y de Manuel de Ubeda el dinero de la lana que les había vendido. Al día siguiente Luis García, cristiano nuevo, entregó poderes a Gonzalo de Baeza para que lo representara en todas las acciones legales que le afectasen. El 18 de marzo Abrayn Abuzeraque, Mahoma Rami y Abrayn el Bergi, moros, vecinos de Graena "por lengua de Hamete Syllero, aljamiado" conceden poderes a Gonzalo de Baeza para que los represente en los pleitos y causas que puedan tener con los cristianos.

El 26 de marzo de 1499 Sireto de Vares adquiere poderes de sus hermanos Bautista y Bartolomé para que junto a Mahoma Guadix lleguen a un acuerdo sobre ciertas cantidades de dinero. Se nombra a Felipe Cigala y a Abrayn Azeyte como jueces arbitros. Estos condenan a Mahoma Guadix a pagar aquellas cantidades ${ }^{26}$.

El 17 de julio Abrayn Alnajar, moro, vecino de Abrucena, "por lengua de Pedro Sangilero" concedió poderes a Ali el Toy, moro, vecino de Guadix, para que lo representase en los pleitos. En estos momentos le afectaba un pleito con Diego de Castro porque le debía cierta cantidad por seda que le vendió. En el contrato se especifican las condiciones de estos poderes. También el 3 de agosto Abdilmelique Aben Momi, alguacil de Abrucena, dio poderes a Diego de Castro para pleitos y cobro de deudas en Guadix y otros lugares. Hizo de intérprete Hamete Sillero, moro, aljamiado, vecino de Guadix.

El 11 de noviembre Ayed Tixo, alguacil de Cortes, Mahoma Abenaben, Maçote Goçey, Ali Talha, Mahoma Abenguyara y Quimel Abenaben, en nombre de los moros de Cortes, dan poderes a Luis de Mendano, procurador, para que los represente en pleitos, causas y otras acciones legales. El intérprete fue Hamete Sillero. El 2 de marzo de 1500 Pedro Sangilero da poderes a Luis de Mendano para que lo represente en todo.

El 29 de julio de 1500 varios mudéjares de Guadix se conciertan con el bachiller Pedro Galán para que los defendiese ante las justicias cristianas. Asi otorgaron Hamete Uleylas, alguacil de los moros de la Morería de Guadix, junto con Hamete Sillero, Ayed Çafán, Ali Benajara, Ali el Toy, Mahoma Benalfiqui, Hamete Romayme, Mahoma Dabaqui, Çaçan Altoy, Ali Sahod, Hamete Lombrón, Maçote Alandaraxi, Ali Mofadal, Mahoma de Gidifuy, Ali Alfaqui Hoçey, Mahoma del Alpuxarri, Çaçan Abenamar y Ali Yaçan, moros, vecinos de la ciudad, que daban su poder y se concertaban con este personaje, y expresaban: "e dixeron que por quanto entre ellos e el bachiller Pedro Galán está platicado e asentado que el dicho bachiller Pedro Galán les ayude como letrado a todos los pleytos asy çebiles como criminales que oy día tienen e tovieren de oy fasta un año primero syguiente, ellos o qualquier dellos o qualquier de los moros desta çibdad e de los lugares de su tierra e de

26. espinar Moreno, M., Álvarez del Castillo, Ma. A. y Guerrero Lafuente, Mª D.: La ciudad de Guadix..., pp. 141-144. 
Finiana, e Habla, e Lahuruçena, e Lapeça, y por ello le dan quinse mill maravedís, pagados por terçios, que agora porque el dicho bachiller Pedro galán les ayude a los dichos pleytos como letrado, e faga de ellos lo que le fuere posyble con tanto quel pleyto que toviere e el oviere de ayudar no sea de moro a moro de los suso dichos ni de los suso dichos lugares". Por su parte el bachiller se compromete a ir a la corte, chancillería, etc., y por ello debe de trabajar y ayudarles en todo. A cambio le pagarán las costas y gastos que pudiera tener. El intérprete fue Felipe Cigala, genovés.

El 2 de septiembre Mahoma de Abenja, moro, vecino de Fiñana, da poderes a Felipe Cigala para que cobre de Mahoma Aben Alferes, vecino de Guadix, 22 onzas de seda, joyante, buena, que le debía de una obligación. También cobrara de Ali Abena 8 onzas de seda. El 30 de octubre Gonzalo de Cortinas, cristiano nuevo, antes Ali Abenomar, vecino de Fiñana, da poderes a Asensio de Santacruz. El 3 de noviembre Rodrigo del Castillo, cristiano nuevo, antes Çaçan Fez, vecino de Paulenca, da poderes a Gonzalo de Baeza para que lo represente en un juicio contra Pedro Iñíguez. Actuó de intérprete Diego López de Ribera. El 4 de noviembre Cristóbal de Zonayte, antes Mahoma de Zonayte, dio poderes a Gonzalo de Baeza. El testigo fue Pedro de Mendoza, antes Hamete Syllero. El 10 de noviembre Lorenzo de Rabaneda, antes Ali Abensalero, dio poderes a Gonzalo de Baeza para que lo representase en todo.

\section{DEUDAS}

La primera deuda que constatamos en la documentación es del mes de noviembre, sin que sepamos el día exacto del contrato. En éste reconoce el mudéjar Mahoma el Rami, "moro", que debe al trapero Diego de Baeza 883'5 maravedíes por un paño de frisa que le había vendido. Se compromete a pagárselo a finales de marzo de 1497. En este contrato se especifica que el moro se somete al fuero y leyes de los cristianos y por ello "renunçió las leyes, e su propio fuero, e çuna, e jara, e dio poder a las justiçias". Igual le ocurre a Mahoma el Rami. El 24 de este mes Mahoma Algayat reconoce que debe al trapero Diego de Baeza 434 maravedíes por otro paño que le había vendido. La deuda quedará saldada a finales de agosto de 1497, como el caso anterior renuncia al fuero, xara y çunna de los mudéjares.

El 13 de diciembre de 1496 Mahomad el Valorí, vecino del Arrabal de Guadix, es decir la Morería, reconoce que debía al genovés Felipe Cigala una libra de seda, joyante, pesada con la pesa morisca de la ciudad. Nos dice que se la pagó a Benajara y se compromete el mudéjar a saldar la deuda a finales de agosto de 1497. En este contrato actuó de intérprete Juan de Valencia.

El jueves 22 de diciembre de 1496 Mahoma el Rami Yça reconoce que debía al genovés Felipe Cigala, o a quien este diera poderes, 32 reales de plata "de a treynta e un maravedís cada real" por un paño de Londres que le 
había vendido. Especifica que estaba contento con la compra y se compromete a pagárselo entero en el mes de agosto de 1497; paga el doble si no cumple lo estipulado en el contrato. Mahoma Bombayre debe a Bartolomé de Bares o a su hermano Bautista de Bares dos libras de seda.

El jueves 22 de diciembre otro mudéjar llamado Mahoma Bombayre debía al genovés Bartolomé de Bares o a su hermano Bautista de Bares, o a quien ellos dieran poderes, dos libras de seda, joyante, buena, pesada con la pesa morisca de Guadix. La compra tuvo un precio estipulado por ambas partes y se compromete a entregar el dinero por Santa María de agosto de 1497. Renunció las leyes, su fuero y jurisdicción, su çunna e xara, etc., y dio poderes a las justicias cristianas para que le pidieran lo que debía o se le pudiese castigar.

Alonso Castellano reconoce deber a Jacome Gentil y a Pedro gentil 1.500 maravedíes por un paño que le dieron. Se lo pagará por San Juan de junio de 1497. Especifica que las justicias pueden exigirle el doble de lo acordado si no cumple el contrato de compra.

El 19 de marzo Yuça Alfida, Hamete Albuchichi, Hamete el Rami y Abdala Marín, vecinos de Guadix, aljamiados, reconocen deber al canónigo Molina 12 reales de plata, de 31 maravedíes, por una partida de panizo que les vendió. Se comprometen a pagarle en octubre. Al día siguiente Mahoma Alcaycas y Mahoma el Murgi, moros, aljamiados, deben a Pedro Gentil 8 maravedies y 4 reales de plata, de 31 maravedíes, por cuatro fanegas de panizo, le pagarán por Santa María de agosto.

El 17 de mayo Ali Abenxaviya, vecino de Ugíjar, moro, "que sabía aljamía" reconoce que debe al genovés Felipe Cigala 128 pesantes "de a treynta maravedís cada pesante desta moneda que agora corre". La cantidad era por una partida de especias, le pagará a finales de agosto. Nos dice el escribano que renunció las leyes, fuero, jurisdión, domicilio, xara, etc., de los mudéjares de Ugijar y se somete al fuero y jurisdicción de Guadix. El 24 de mayo Abrayn Amilet debe al trapero Juan Quesada 13 reales de plata por un paño, se compromete a pagarle en 60 días. Hizo de intérprete Hamete el Caçar.

El 4 de diciembre de 1497 Ali Çaçan se compromete a pagar al cristiano nuevo Fernando Fernández 5.000 capullos de seda, buena, por un capuz que le entregó. La deuda la saldará en el mes de agosto de 1498. Hizo de intérprete Luis González, cristiano nuevo, vecino de Guadix.

El 9 de diciembre Mahomad Gali debe a Pedro Díaz de Navarrete 600 maravedíes por unas frisas, las pagará en agosto. El intérprete fue Gerónimo de Huéscar. El día 13 Hazen Talha, moro, aljamiado, y su esposa Homalfata reconocen deber a Bernaldino de Bares o a su hermano Bautista 40.000 capullos de seda, buena, "que de tres mil salga una libra de seda hilada, y si no saliere que los cumplirán al dicho respecto". Estos eran porque recibieron unos quesos y se comprometieron a pagarle en agosto. El 17 Haçan Talha debe a Juan de Herrera 1.612 maravedíes por un rocín castaño. Igual le ocu- 
rre al día siguiente a Hamete Albeazi por otro rocín que le entregó este vendedor. El 19 Mamete Albeazi debe a Francisco de Rabaneda, cristiano nuevo, 2.250 maravedíes por un potro castaño. Los testigos de este contrato fueron Hamete Romayme y Haçen Talha, algo aljamiados, y el intérprete Juan Alvárez. E1 31 de diciembre Yuça Navarro reconoce deber a Manuel de Ubeda 1.290 maravedíes por cierto pan que le vendió. Le pagará por el fiesta de Santiago de 1498.

En 1498 encontramos varios contratos de deudas, así el 23 de marzo Ali Benajara, moro, algo aljamiado, expresa que le había pagado Rodrigo de Avalos 4.000 capullos de seda porque le debía 10.000 maravedíes de los trabajos de una acequia. El 26 Hamete Romayme, moro, aljamiado, reconoce que debe a Jacome Gentil 6.224 maravedíes por una cantidad de especias que le vendió, se lo pagará en cuatro meses a partir del contrato. También Hamete Azeytuni y Mahoma Dinar, moros, reconocen el 11 de mayo que debían a Martín de Hervás 15 reales, de 34 maravedíes, por la hoja de unos morales en Luchena, entregarán el dinero por San Juan de junio. Mahoma Jaylud se compromete a pagar a Luis de Cazorla, o a su hermano Alonso García, una libra de seda, buena, joyante, pesada con la pesa de Guadix. También Alí Bengayara, moro, vecino de Cortes, y Hamete Çajar, reconocen que deben a Luis de Cazorla una libra de seda. El intérprete es Mahoma Bombayre. El 14 de mayo Mahoma Rami debe a Juan de Alarcón 900 maravedíes por un paño.

Omar Xaudari, moro, vecino del Ciguení debe a Felipe Cigala el 16 de mayo 4.000 capullos "que de tres mill capullos salgan una libra de seda hilada, e sy no que lo cumpla al respecto". El intérprete fue el cristiano nuevo Gonzalo de Huéscar. Por su parte Pedro Gentil reconoce que Hamete Abenja, vecino de Fiñana, se había obligado con Martín Díaz, criado de don Alvaro de Bazán, para que le entregase dos libras de seda como se especifica en el contrato realizado ante el escribano Lope de Molina. En realidad eran seis libras pero cuatro de ellas las entregó Martín Díaz y el resto Mahamete. Se hizo carta de pago y finiquito de la seda y otro documento entre Pedro Gentil y Martín Díaz. E1 9 de junio Mahoma Marracoxi, moro, hijo de Ali Marracoxi, aljamiado, debe a Jacome Gentil 3 libras de seda. El 11 de junio Mahoma Aben Mote, moro, aljamiado, debe a Francisco de Rabaneda, cristiano nuevo, 5.000 capullos de seda "por razón de que gelos compró, a noventa e tres maravedís cada millar". Le paga en el plazo de un mes y medio. El intérprete fue Mahoma el Toy.

El 11 de enero de 1499 Alí Tamanite y su esposa Malfata deben a Felipe Cigala, genovés, 1'5 libras de seda, pesada con la pesa morisca de Guadix, de buena calidad y del tipo joyante. Le abonarán el importe en el mes de agosto. El intérprete en el contrato fue Ali Benajara. El 14 de enero Mahoma Alabedi, moro, debe a Francisco Chamorro, o a quien éste designara, 4 libras de seda, joyante, buena, pesada con la pesa morisca de la ciudad porque le 
entregó un paño. El plazo para saldar la deuda era el mes de agosto. Actuó como intérprete Pedro Sangilero. El 15 Ali Alcafala, moro, debe a Francisco Chamorro una libra de seda por otro paño. Le pagará el día de San Juan de junio. El intérprete fue Alonso de Salamanca. El 24 de enero Çaçan el Feçi, moro, debe a Luis de Cazorla 460 maravedíes por un paño. Se compromete a pagarle para Santa María de Agosto. Actuó de intérprete Hamete Benalfiqui, hijo de Benaxi, aljamiado.

El 31 de enero de 1499 otorgó Haxa, vecina de Jeres del Marquesado "por lengua de Miguel Ruys, yntérprete", vecino de Guadix, que debe al cristiano nuevo Luis de Acuña, vecino de Çújar 45 miscales, de a 30 maravedíes, por una deuda de su hermano Ali Xaudari. Esta deuda habia llevado al Xaudari a la cárcel pública "por los quales el dicho Luys de Acuña tenía preso al dicho Xaudari, e le soltó, e se lo dio, de la qual obligaçión por donde el dicho Xaudari le devía los dichos maravedís". Esta se compromete a entregarle el dinero en treinta días. A su vez Luis el Xaudari se compromete a pagar 226 maravedíes a Luis de Acuña que se los había prestado por hacerle un favor. Los devolverá en veinte días.

El 9 de febrero Hamete Albeazi, moro, vecino de Guadix, debe a Bartolomé de Bares 1.980 maravedíes por 3 libras de azafrán que le vendio a 670 maravedíes la libra. Se lo paga para Santa María de agosto. En esta fecha Luis de Acuña, cristiano nuevo, debe otras 3 libras de azafrán a Hamete Albeazi que suman 1.960 maravedíes.

El 10 de febrero Mahoma de Aloaymar, vecino de Muñana, en el río Alhama, debe a Diego Muñoz 1.380 maravedíes por un asno. Hizo de intérprete Ali Mays y Hamete Alasar, aljamiados. También Ali Mays debe a Diego Muñoz 450 maravedíes por otro asno. El intérprete fue en esta ocasión Hamete Laçar, aljamiado. El 13 de febrero Alonso Calderón el Gordo, vecino de Baeza, reconoce que le debe al cristiano nuevo Fernando de Acuña 200 maravedíes por una deuda de su sobrino Rodrigo a quien le entregó unas tazas de arribol. Se comprometen a pagarle en mes y medio.

El 15 de febrero Mahoma de Abuychi, moro, debe a Bartolomé de Bares 1.320 maravedíes por dos libras de azafrán. El intérprete fue Luis de Acuña. El 16 Çaly, moro, aljamiado, vecino de Paulenca debe pagar a Diego Muñoz 4.000 capullos de seda a finales de agosto.

El 19 de febrero ante el corregidor de Guadix se presentó Mahoma Maçería, moro, vecino de Tremecén, y por lengua de Hamete Sillero expuso que el señor corregidor había ordenado tomarle algunos bienes y mercaderías en la ciudad de Almería. Esto se hizo por petición de Fernando de Hellín al no querer pagar algunas doblas en el reino de Tremecén. Ahora da poderes a Ali Benajara para que pague las deudas y derechos que corresponden a los monarcas. Estaba ordenado pagar de todas las mercaderías que entraban y salían de Tremecen y de Almería. Tenía como fiador a Ali Benajara. 
El 26 de febrero Mahoma de Adurrame, moro, como principal deudor, y Mahoma Venzaylon, como fiador, reconocen que deben a Diego Muñoz 1.380 maravedíes por un caballo rucio. Los paga en el mes de octubre. El intérprete fue Pedro Sangilero. También Alí Mays, moro, aljamiado, vecino de Guadix, debe a Simón Rodríguez 780 maravedies por una mula castaña. Les pagará por Pascua Florida. El 8 de agosto quedó libre de la deuda y se expidió carta de pago y finiquito. Yuça Felimine, moro, color moreno, aljamiado, hornero, vecino de Guadix debe a Bartolomé de Bares, genovés, una libra de seda, hilada, joyante, buena, acabará de pagarle en Santa María de agosto.

El 5 de marzo de 1499 Manuel de Ubeda, arrendador de las rentas de los monarcas en Guadix y su partido del año de 1497, y en nombre de su hermano Fernando Manuel, como arrendador de las rentas de los reyes de 1498 y 1499, especifica que tienen cartas para cobrar ciertas rentas, entre ellas "les a pertenesçido e pertenesçen la pena de los moros borrachos, la qual porque mejor se supiese la verdad de los dichos moros borrachos, e fuese en ellos esecutada la dicha pena, que avían encomendado e dado poder a Fernando de Galves, e a Juan Hortun, alguaziles desta çibdad, e a Juan Péres de Çamudio, e a Pedro Sánches, alguaziles que fueron desta çibdad, para que cobrasen la dicha pena de los dichos borrachos". Tras cobrar las penas dieron cartas de pago. Se compromete Manuel de Ubeda a dejar libres de cargos a cada uno de los alguaciles. Conceden otra carta de poder a Fernando de Galves y a Juan Hortun para que continúen cobrando la renta de los moros borrachos y puedan dar cartas de pago, aparecer en juicios y realizar otras acciones legales.

El 10 de marzo de 1499 Hamete Abençafia o Abenjafa reconoce deber a Diego Muñoz 2.000 capullos de seda "buenos y tales de dar y de tomar por razón que gelos conpró e pagó a preçio que con él se convino". El resto los entrega para Santa María de agosto.

El 23 Ali el Fayçi, moro, vecino de Ferreira, debe a Francisco de Rabaneda 1.350 maravedís por 5 arrobas de lino. Le paga a finales de agosto. Fueron intérpretes Abrayn Azeyte y Mahoma Romayme, aljamiados. El 29 de marzo Simón Ruiz, vecino de Guadix, se compromete a pagar a Antonio de Rabaneda 1.760 maravedíes, se los debía un moro de la Calahorra por unas prendas que le tomó Rabaneda. El 4 de abril Mahoma el Labidi, moro, vecino de Guadix, debe una libra de seda a Felipe Cigala. La seda o su precio a primeros de agosto. Actuó de intérprete Ali Benajara. También el 6 de abril Mahoma Dalfequi, vecino de Abla, se compromete a dar a Felipe Cigala dos libras de seda "joyante, buena, hilada, pesada con la pesa morisca de Habla por razón que gela conpró". Actuo de intérprete Cayde, moro, aljamiado.

El 9 de mayo Pedro de Guadix y Gonzalo de Sanpedro, cristianos nuevos, deben a Jacome Gentil 30.000 maravedíes por 50 varas de paño de Londres de colores y 3 arrobas de especias. La deuda la saldan en diez meses o las justicias de la ciudad pueden actuar contra ellos. 
El 8 de junio de 1499 Fernando de Frías hace constar que Pedro de Guadix, cristiano nuevo, le debe 1.500 maravedíes por una obligación y plazo. Ahora reconoce que se los pagó y le concede carta de pago, se compromete a no exigírselos. El 24 de junio Alonso de la Cuesta, hijo de Benito de la Cuesta, vende una mula a Ali Mays y a Hamete Alaçara por 1.550 maravedíes. La bestia era de color castaño. Los dineros los entregarán en dos meses. El 26 de junio Mahoma Çamid "algo aljamiado" debe al vicario Pedro de Herras 180 fanegas de cal que le había comprado al precio que estipularon. Se comprometió a llevar la cal hasta la boca de la calera. La mitad la tendrá para el mes de septiembre y la otra para octubre. El vicario tiene que trasladar la cal desde la calera a la obra a su costa. El 17 de julio Juan de Santillana, tendero, vecino de Guadix, expone que su esposa había empeñado un paño morisco, labrado por los cabos.

El 3 de septiembre Bautista de Bares expresa que Mahoma Guadixi le debe por una obligación y sentencia 11 libras de seda. Tras pagárselas se rompió la obligación. El 17 de septiembre Ali Benajara dice que Gonzalo Núñez le debe en Cogollos de Guadix 15 libras de seda por una obligación efectuada ante Lope de Molina, escribano; por ellas salió Jacome Gentil como pagador de la deuda.

El 15 de este mes Çad Chahobile, moro aljamiado, vecino de Guadix, debe a García de Hogaya 750 maravedíes por un rocín rucio, manco y ciego. Le paga a finales de marzo del 1500. El 16 de noviembre Gonzalo de San Pedro, cristiano nuevo, debe a Felipe Cigala 10.710 maravedíes por unas frisas, se compromete a pagar a mediados de agosto. El 27 de noviembre Yayd Lupe y su mujer Fortuna, vecinos de la ciudad, deben a Felipe Cigala una libra de seda, joyante. Le paga a primeros de agosto. El intérprete fue Mahoma Benalfaqui.

El 30 de septiembre de 1499 los monarcas expiden una pragmática que alcanza a todos los súbditos en la que prohíben utilizar brocados, seda, chamelote de seda, zarzahán, tercenel y tafetán en las ropas de vestir, forros, caparazones, viznas, correas de espada, cinchas, sillas y alcorqués. También bordados de seda, chapados de plata y oro de martillo, sea tirado, hilado o tejido, etc.; respecto a los mudéjares de Granada y Guadix se les permite llevar las ropas tradicionales ${ }^{27}$.

El 2 de diciembre Hamete Yuça, moro, vecino de Guadix, "algo aljamiado" otorga que el cadí moro había prendido a Abdilmelique, moro, por unas deudas que fio a su mujer. Hamete Yuça sale como fiador, se compromete a saldar todo lo que debía Abdilmelique " e pagara lo juzgado, so pena quel pagará todo lo que contra el dicho Adulmeliqui fuere sentençiado e jusgado

27. Seco de Lucena Paredes, Luis: «Sobre la favorable disposición de los Reyes Católicos hacia los musulmanes vencidos», MEAH, II, pp. 127-129. 
con el doblo". El 20 de este mes Hamete Dinar, moro, algo aljamiado, vecino de Guadix, debe a Felipe Cigala una libra de seda, joyante, pesada con la pesa de la ciudad.

El 15 de febrero del 1500 Yuçaf Almaleque, moro, vecino de Guadix, debe a Felipe Cigala una libra y media de seda por una frisa, le paga a principios de agosto. El 24 de febrero Çaçan el Cambili, moro, debe a Jacome Gentil 5.740 maravedíes por 90 fanegas de panizo y 10 de trigo. Entrega la mitad del dinero a finales de mayo y el resto a finales de octubre. Los testigos fueron Felipe Cigala, Hamete Sillero y Çad Abenalfaes.

El 9 de marzo Hamete Sillero, moro, aljamiado, sale como fiador de Çaçan Açamar, vecino de Aldeire, que estaba preso en la cárcel pública de Guadix. Se comprometió a entregar 30.000 maravedíes a la Cámara de los reyes que era la cantidad adeudada por el preso. Los vecinos de Aldeire, Hamete el Zoluyque y Ali Abençoron se comprometen a sacar a salvo a Hamete Sillero de la obligación contraída para sacar de la cárcel a Açamar. El intérprete fue Bautista Moço.

El 16 de mayo Ali Turron, moro, debe a Martín de cambil 216 maravedíes porque le prestó un castellano y se lo devolverá por San Juan. Actuó de intérprete Maçote Abençafi. El día 20 Ali Almarçeni, moro, vecino de Guadix, tintorero, debe a Felipe Cigala 3.562 maravedíes por una cantidad de anir. Los testigos fueron Mahoma Navarro, alpargatero, Ayed Abenfari y Ali Giber, todos aljamiados.

El 20 de junio Gonzalo Núñez, Mahoma Benalfaqui, Hamete Benalfaqui, su hijo, Ali Marracoxi y Mahoma Marracoxi, vecinos de Guadix, deben a Jacome Gentil 42.000 maravedíes por 400 arrobas de aceite, a 105 maravedíes la arroba. Se especifica en el documento que éste sería "puesto en Almería, puerta afuera, medido con la medida que compran e venden en Almería, lo qual ellos trayan a su costa". Saldarán la deuda por San Juan de 1501.

El 19 de julio Ali Yaçan, moro, debe a Pedro Sangilero 4 arrobas de lino, bueno, limpio, pesado con la pesa morisca de la ciudad, le pagará a finales de octubre. El 9 de agosto Abdala Rondi debe a Manuel de Ubeda 40 fanegas de trigo a 75 maravedíes la fanega, que suman 3.000 maravedíes. Le pagará en dos meses. Al día siguiente Ali Yaçan debe a Pedro Sangilero dos arrobas de lino. El 26 de octubre el cristiano nuevo Fernando de Mendoza, antes Abrayn Albamar, debe a Diego Muñoz 408 maravedíes por un capuz. El 2 de noviembre el cristiano nuevo Pedro Fernández debe a García de Baena 300 maravedíes por un paño. Le pagará en Navidad.

El 26 de octubre del 1500 Pedro de Guadix debe a Felipe Cigala 1.410 maravedíes por unas frisas. Le traspasa varias cartas de deudas de mudéjares de Guadix y su tierra, con estas cantidades deja saldada la cuestión ${ }^{28}$.

28. espinar Moreno, M., Álvarez del Castillo, Ma . A. y Guerrero lafuente, Mª D.: La ciudad de Guadix..., pp. 174-175. 
El 15 de diciembre del 1500 una carta de finiquito nos informa de hechos importantes para Guadix y su tierra. Francisco el Toy, cristiano nuevo, antes Çaçan el Toy, y María, su mujer, antes Malfata, y Zacarías, antes Mahoma el Toy, padre del dicho Francisco el Toy, y tío de la dicha María, todos vecinos de la ciudad de Guadix, exponen lo siguiente: "que por quanto avra catorze o quinse años que murieron Çaçan Altoy e Fatima, su muger, sus padre y madre de la dicha María, e ella quedó por heredera de todos los bienes de los dichos sus padre e madre, e porque no hera de hedad, quedó por testamentario, e albaçea, e guardador de la dicha María, e de los bienes de los dichos sus padre e madre, que ella heredava, don Francisco el Toy, que primero se llamava Çaçan Altoy, vezino de Xeres, el qual tomó e tovo los bienes de los dichos sus padre e madre de la dicha María en guarda e encomienda como testamentario, e que por quanto al tienpo que se tomó esta çibdad de Guadix de christianos, se perdieron los bienes rayzes que ella heredava de los dichos sus padres, e al tienpo que se perdió Fyniana e su ribo, se perdieron los bienes muebles, e de lo que quedó en poder del dicho don Francisco el Toy él pagó por la dicha María a Handa, mora, su aguela, muger de Majarra, çierta contía de maravedís, los quales le dio por el tienpo que la dicha su aguela la tovo e cryó, que la dicha María por sy, e con la dicha liçençia, e el dicho Francisco el Toy, su marido, e el dicho Zacarías, e todos de mancomun an por bueno, firme, e valedero asy los maravedís que dio a la dicha su aguela, como todo lo otro que el dicho don Francisco el Toy fizo, e aya fecho de los bienes que quedaron, e él resçibió de los dichos su padre e madre, e que se davan e dieron por contentos dellos por quanto se perdieron e los pagó el dicho don Francisco el Toy, segúnd dicho es. E que se partían, e quitavan, e renunçiavan qualquier herençia, derecho, avçión, que a los dichos bienes de los dichos sus padre e madre de la dicha María tengan por razón de la dicha herençia o en otra qualquier manera, por quanto los dichos bienes se perdieron como dicho es, e que davan e dieron por libre e quito al dicho don Francisco de todos e qualesquier bienes que aya resçibido e quedaron de los dichos sus padre e madre..". Actúan de testigos Asensio de Santacruz y de intérprete, Francisco de Acuña, antes Ali el Toy, Francisco Pérez, antes Mahoma el Toy, intérpretes, y Diego de Barrionuevo.

Este mismo día don Francisco el Toy, vecino de Jeres daba a María, mujer de Francisco el Toy, 13.980 maravedíes en dote. Los dio en esta manera: 287 pesantes en dineros cuando se casó y otros 25 en una almalafa, otros 25 en un capuz para Francisco, 129 pesantes en una casa que compró a Francisco el Toy y a Zacarías. Le entrega todo y renuncia a todos los derechos que puedan obligar a María a pagarle aquellas cantidades.

\section{ARRENDAMIENTO DE CASAS}

El 8 de diciembre de 1497 Gonzalo Núñez arrienda a Mahoma Quirquir, moro, aljamiado, una casa en el Arrabal de la Morería "donde agora está el lino del diezmo". El arrendamiento es por un año y comienza a contar desde 
el 1 de enero de 1498. Le entregará un real de 34 maravedíes al mes y dos gallinas al año. En total 12 reales y dos gallinas por Navidad. Tendrá la casa reparada o entregará de pena 2.000 maravedíes. Este cristiano el 11 de diciembre arrienda a Haçen Talfa otra casa en el Arrabal de la Morería por 18 reales y 2 gallinas al año. La vivienda estaba junto a Santa Ana donde residía Haçen. Le cede la casa por un año y le pagará en dos plazos, por San Juan y Navidad en que le hace entrega de las gallinas. El 19 de mayo Gonzalo Núñez da a censo perpetuo a Ali Yaçan, moro, aljamiado, un corral con unas cuevas en el Arrabal de Santa María. Lindaban con el Marracoxi, moro, con Fernando del Castillo y una calle Real. La renta era de 155 maravedíes y una gallina al año, le paga la mitad por San Juan y el resto por Navidad. Se atiene a lo estipulado en los censos perpetuos y no puede venderlo sin permiso del dueño.

El 25 de enero Ali Benajara, "moro, algo aljamiado" sale fiador de Muça Namile que estaba preso por derribar unas casas. El hecho fue denunciado "sobre lo qual avia yncurrido en pena". Paga las multas y daños que estipularon las justicias de la ciudad. El 26 de enero Diego de San Martín vende unas casas a Benito de Vitoria por 6.000 maravedíes. Entre los testigos encontramos a Hamete de Vejar y Ali de la Calle, vecinos de Granada, moros, aljamiados. Se expide un documento en el que especifica que le queda a deber 4.000 maravedies a pagar por Pascua Florida.

El 16 de abril de 1499 Pedro Polido vende en Guadix una casa con sus corrales al cristiano nuevo Luis de Guzmán. La vivienda estaba en el Arrabal de Granada, junto a casas de Alvaro Carrillo y de Martín de Hervás. El precio fue de 3.000 maravedies. La vende "con todas sus entradas e salidas, e como él las tiene e posee". Le hace donación de la demasía y se comprometen a respetar el contrato. Los testigos fueron Pedro de Linares, Lope de Legaspi y Juan Hortin, alguacil, todos vecinos de Guadix. Abona los dineros por San Miguel de Septiembre del 1500. El 5 de octubre de 1499 saldó la deuda y expidió Pedro Polido un documento a Luis de Guzmán. Actuó de testigo Miguel Sánchez.

El 30 de abril Gonzalo Núñez, vecino de Guadix, da a censo de por vida a Hamete Alhaje, moro, vecino de Paulenca "aldea desta çibdad" y a uno de sus herederos una casa con sus cuevas en Paulenca. Estaban habitadas por Hamete Alhaje en el momento del arrendamiento. Paga de censo 102 maravedíes y 3 gallinas vivas, buenas, de dar y tomar, en cada un año por San Juan. Si durante dos años deja de pagar lo estipulado perderá los derechos. No puede venderlo a la iglesia, monasterios, caballeros, etc., a no ser a otra persona de su condición, y, en este caso, lo comunicará a Gonzalo Núñez para obtener su permiso. Debe conservar la vivienda en buen estado "e que tenga la dicha casa e cuevas labradas e reparadas a lo menos como el las resçibe por manera que valgan el dicho çenso". Ambas partes se comprometen ante las justicias. Entre los testigos de este contrato encontramos a Gonzalo 
de Baeza, Diego Muñoz y Gali Dabulquirate, moro, aljamiado, alguacil de Paulenca, que actuó de intérprete.

El 20 de junio de 1500 Gonzalo Núñez arrienda a censo perpetuo a Mahoma Benalfiqui, moro, y a su hijo una casa en el Arrabal de la Morería, alinda con otras casas de Gonzalo. Le paga dos gallinas y se obliga a repararla.

En una carta de 15 de agosto de 1500 Leonor de Navarrete vende a Sancho de Benavides una casa en el lugar de Albuñan, cerca de la mezquita.

El 24 de diciembre del 1500 Martín de Mino arrienda a Cristóbal de Benavides, cristiano nuevo, antes Aly Mays, una casa en el Barrio Nuevo, alinde de huerta de Martín de Mino. Se la da por 3 años para que viva, se aproveche y le pague de renta 18 reales, de a 31 maravedís, y dos gallinas al año por el día de Navidad. Se especifica que si algo tiene que arreglar o reparar lo haga a costa del alquiler.

Este mismo día Martín de Mino arrienda a Francisco Xavali, cristiano nuevo, antes Abeayd Jabali, vecino de Guadix, una casa en el Barrio Nuevo, junto a otras de Martín de Mino. Se la arrienda por 3 años y le cobra 15 reales, de a 31 maravedís, que suman 465 maravedíes más dos gallinas al año, pagado por Navidad. Se especifica que si algo tiene que adobar o reparar en la casa que lo repare a su costa y lo desquite del alquiler con permiso del dueño. Se compromete Martín el Mino a no quitársela y si lo hace le entregará otra y perderá el alquiler. El arrendatario se compromete a cumplir todo lo estipulado en el contrato.

\section{RENTAS DE LA MORERÍA}

El 3 de mayo de 1497 el corregidor Diego López de Trujillo y varios regidores se conciertan con Antonio de Rabaneda, gobernador del Cenete, que actúa en nombre del marqués don Rodrigo, para que la ciudad un baño del marqués y obtenga un tercio de los ingresos, se especifica "agora sea renta rentada, agora por conçierto con los moros desta çibdad"29. También algunas penas de los cristianos nuevos se destinan a blanquear la alhóndiga. Se le pagan varios cantidades al moro Cortezo por trabajar en las obras de la carnicería ${ }^{30}$. Otros mudéjares participan en las obras de la construcción de un pilar y las penas impuestas a algunos de ellos sirven para comprar materiales, entre estas penas se alude a que no pagaron los derechos por vender miel ${ }^{31}$.

El 16 de junio de 1498 Hamete Uleylas, moro, alguacil de los moros de la ciudad y su tierra, aljamiado, expone que era alguacil y almotacén de los

29. Ibídem, p. 84 .

30. Ibídem, pp. 88-121.

31. Ibídem, pp. 124-126 y 137-140. 
mudéjares de Guadix y su partido por unas cartas de merced de los Reyes Católicos. Ahora se presenta ante el corregidor para que le de un mandamiento con el reconocimiento de los dos oficios. Su intención era de dar poderes a dos mudéjares para que cobraran las rentas y realizaran otros trabajos relacionados con estos cargos.

El 11 de enero de 1499 Nicolás Vergara que cobra la renta del viento de la Morería de Guadix expone a la justicia que ésta era de las rentas ordinarias, le deben de conceder un documento para que la pueda cobrar. Le solicitaron que entregase algunas cantidades para expedirle las cartas de fieldad y con ello que le acudiesen con los derechos que pertenecían a la renta. Dio poder a Mahomad Benalfaqui para cobrar todo.

El 5 de marzo de 1499 Manuel de Ubeda, arrendador de las rentas de los monarcas en Guadix y su partido del año 1497, y en nombre de su hermano Fernando Manuel, arrendador de las rentas de los reyes de 1498 y 1499, especifica que tiene cartas para cobrar ciertas rentas entre ellas "les a pertenesçido e pertenesçen la pena de los moros borrachos, la qual porque mejor se supiese la verdad de los dichos moros borrachos, e fuese en ellos esecutada la dicha pena, que avían encomendado e dado poder a Fernando de Galves e a Juan Hortun, alguaziles desta çibdad, e a Juan Péres de Çamudio e a Pedro Sánches, alguaziles que fueron desta çibdad, para que cobrasen la dicha pena de los dichos borrachos". Tras cobrar dieron cartas de pago. Se compromete Manuel de Ubeda a dejar libres de cargos a cada uno de los alguaciles al saldarle todas las deudas. Conceden otra carta de poder a Fernando de Galves y a Juan Hortun para que continúen cobrando la renta de los moros borrachos, den cartas de pago, aparezcan en juicio y otras acciones legales relacionadas con todo aquello.

El 15 de febrero del 1500 Nicolás de Vergara, criado de Gonzalo Núñez, otorgó que había sacado en almoneda pública la renta del viento de la Morería de Guadix, estaba en 61.000 maravedíes. Hizo de fiador de esta cantidad Gonzalo Núñez y se quedó con ésta para cobrarla. Expresó que recibe la renta y traspasación, paga los 61.000 maravedíes al rey y la reina, o sus representantes, pues así lo había hecho Nicolás de Vergara. Se atiene a las leyes del cuaderno y a lo que le piden los recaudadores y contadores reales.

El 4 de noviembre Francisco Zambrano, antes Hamete Abenamar, expone que Jorge Navarro, antes Abrayn Navarro, había cobrado ciertos derechos de la renta del almuxit que le pertenecían a él como mayor ponedor de ella. Le pide que le entregue cuentas de lo recaudado hasta aquellos momentos.

El 12 de diciembre del 1500 el bachiller Fernando Carrillo, teniente en los oficios de la justicia de la ciudad, y García de Arana, Luis de Madrid y Francisco de Arana, regidores de Guadix, expresan que conforme a las leyes del cuaderno hicieron pregonar los derechos de las alcabalas, de la seda y otros derechos, que los cristianos nuevos estaban obligados a pagar a los monarcas en 1501. Hasta aquellos momentos no había ponedores. De acuerdo 
con estas leyes ponen por fieles de las alcabalas, derechos de la seda y otros, en Guadix y su partido, a Fernando Manuel y a Manuel de Ubeda. Estos se comprometen a tener libro y cuenta de los derechos y entregar cartas de pago.

E1 23 de diciembre Fernando Manuel y Manuel de Ubeda, como fieles de las alcabalas y derechos de los monarcas, dan poderes a Asensio de Santacruz para que cobre aquellos derechos y conceda cartas de pago.

\section{HORNOS DE PAN}

Los hornos de pan fueron importantes en los barrios de las ciudades y de las alquerías. La mayoría de ellos dependían de las mezquitas. Las rentas y beneficios se destinaban a los gastos de los alfaquíes. Así en 1494 en el arrendamiento efectuado por Sancho de Benavides a los mudéjares se especifica que el horno lo construyen los vecinos y la renta es para el alfaquí que les atiende. En 1497 en un documento de 26 de noviembre se alude a un arrendamiento de un horno por parte de Fernando de Galvez a Leonor Díaz. El horno estaba cerca de la Morería en el Arrabal de Santiago de Guadix.

El 5 de enero de 1501 se redacta un documento, interesante para el estudio de los mudéjares y moriscos de Guadix; es un contrato con la iglesia para seguir teniendo unos hornos en el Arrabal de la Morería de la ciudad. Dice así:

"Este día otorgaron, por lengua de Francisco el Toy, que se dezía Ali el Toy, e por lengua de Çacarias Romayme, que se dezía Hamete Romayme, Pedro Gentil, que se dezía Mahoma Benalfiqui, e Antonio de Ravaneda, que se dezía Mahoma de Alhoamiça, e Francisco de Mira, que se dezía Mahoma el Galari, e Diego de la Cueva, que se dezía Ayed Açeyque, e Gonçalo de Cortinas, que se dezía Mahoma Cortezo, e Pedro de Andaraxi, que se dezía Maçote el Andaraxi, e Nuño de Mata, que se dezía Mahoma Bonbayre, e Juan de Tarifa, que se dezía Mahoma Dumaya, e Diego Riquelme, que se dezía Alí Giber, e Bartolomé Quirquix, que se dezía Mahoma Quirquix, e Alonso Gutierres, que se dezía Alí Çot, e Fernando Aben Xuaybi, que se dezía Ali Aben Xuaybi, todos nuevos chistianos, e vezinos desta çibdad, de mancomun, etc. Que por quanto Diego Lópes Benaj̧ara, que se dezía Alí Benajara, e Pedro de Mendoça, que se dezía Hamete Syllero, en tienpo que heran moros, ellos e Martín Riquelme, que se dezía Ayed Çafan, e Juan de Sant Pedro, que se dezía Ali Yaçan, açensaron tres hornos de la yglesia, el uno caydo, que son en el Arrabal de Barrio Nuevo desta çibdad, y un solar de otro horno, por los quales todos se obligaron y deven dar a la yglesia por los suyos ocho mill e seteçientos maravedís, e por el de la çibdad çinco mill, esos cada un año para syenpre jamás, segúnd se contiene en las cartas que dello hizieron, que por quanto los tomaron a çenso para el aljama, syendo moros, que agora que son chistianos, que ellos tomavan e tomaron para ellos, e para los otros christianos desta çibdad, los dichos hornos a su cargo por el dicho çenso quellos tomaron, e que se obligavan e obligaron de pagar todos los dichos maravedís del dicho çenso a la 
dicha yglesia, e a la çibdad, a los plasos, e so las penas, e como e segúnd ellos están obligados, e de los sacar a pas e a salvo de las obligaçiones e cartas que sobre los dichos çensos hizieron, so pena de les pagar los dichos maravedís del dicho çenso con el doblo, e mas [las costas] que sobre ellos se les syguieren, para lo qual obligaron sus personas, e bienes, e [renunçieron las] leyes, e dieron poder a las justiçias, e [otorgaron] carta en forma, etc.

Testigos los suso dichos ynterpetres, e Alonso..., que se dezía Çad Alhobir, e Nicolás San.."

\section{TRABAJOS A SOLDADA}

El 29 de enero de 1499 otorgó Elena, negra, cristiana nueva, vecina de Guadix, que entregaba a su hijo, negro, llamado Antón para que estuviese a soldada con Juan Parrado. El niño de 10 años estaría a su servicio por 10 años. Le sirve a cambio de comida, bebida, vestido, calzado y cama en que dormir; además, se compromete a que tenga una vida razonable y a no ordenarle nada que no sea honesto. Le pagará al final de los diez años de servicio 5.000 maravedíes. La madre se compromete en caso de que se vaya el muchacho a tornarlo en el plazo de seis días tras ser requerida por Juan Parrado, o por otro con su poder. Si no es así perderá lo servido y pagará de pena 3.000 maravedies. Recibió con estas condiciones Juan Parrado a Antón y se obligó a todo lo estipulado en el contrato.

El 12 de mayo de 1500 otorgan Fernando del Castillo y Juan Garrido, cristianos nuevos, que entran a soldada con Ali Avena, moro, para servirle en el oficio de herreros durante seis meses. Les da a cambio de su trabajo 68 maravedíes al día, libres; serán pagados semanalmente a cada uno de ellos la parte que les corresponda "e contando en el dicho serviçio mes entrado mes salido".

El 3 de noviembre del 1500 Fernando de Mendoza, alcaide del Alcazaba de Guadix, se concertó con el cristiano nuevo Gonzalo de Cortinas, antes Mahoma Cortezo, para realizar unas obras en la iglesia de San Sebastián. El dicho Cortezo tomaba a censo y destajo las obras en aquella iglesia para hacer las tapias con rafas de ladrillo en las esquinas. El precio era de 34 maravedíes la tapia y recibe la cal, arena, ladrillos, vigas labradas y los materiales necesarios a pie de obra. Especifican que construirá cuatro pilares de ladrillo y labrará dos vigas para asentarlas con sus cantos por el precio de 500 maravedíes. La otra debe acabarse en el plazo de tres meses. Para que comenzase a trabajar le pagó 750 maravedíes.

\section{EL GANADO}

El 30 de noviembre de 1499 Nuño de Mata, antes el Bombayre, dio poder a Luis de Mendano para que pueda pedir y demandar de Maçote, el 
Negro, un buey que le dio a guardar "e le pagó su trabajo de la guarda". Le solicita carta de pago y la devolución del animal.

El 10 de diciembre del 1500 Francisco el Toy, cristiano nuevo, antes Çacan el Toy, dio a Pedro Dinar, cristiano nuevo, antes Maçote Dinar, unos ganados cabríos de 134 cabezas. Lo entregó para que lo trajesen al campo y lo guardasen bien, durante cuatro años. Por el trabajo de guardar y cuidar el ganado le da la mitad del esquilmo, leche, quesos y cabritos de todo lo que las cabras produjesen. La otra mitad estaría obligado a entregarla al dueño cada año. Al final de los cuatro años Pedro Dinar está obligado a devolverle las 134 cabras y dar cuenta exacta de todo lo que habían producido o multiplicado; si no lo hace así le pagaría $16.429^{\prime} 5$ maravedíes en que eran apreciadas las cabras que le entregaban. Además de lo que se apreciare que podía valer el esquilmo del ganado de aquellos años, pagado en ganado cabrío o en dinero en el plazo de diez días. Si por culpa o negligencia de Pedro Dinar se pierde alguna cabeza de ganado la pagará, si esto ocurre sin su culpa le entregará el pellejo de la cabra y queda exento de pagarle. Si Francisco el Toy le quita el ganado le pagará la mitad del esquilmo y las ganacias de aquel tiempo. Hicieron dos cartas de este contrato. Actuaron de testigos Francisco de Acuña, antes Ali el Toy, Francisco Pérez, antes Mahoma el Toy, Francisco de Antequera, antes Çaçan Antiquiri, Francisco Arias y Alonso Pérez de Navarrete.

Este mismo día Francisco el Toy dio a Francisco Dinar, antes Hamete Dinar, 105 cabezas de ganado cabrío con las mismas condiciones que el contrato anterior. La cantidad a devolver era de $8.203^{\prime} 5$ maravedíes en que se apreció el ganado. Actuan los mismo testigos.

\section{ESCLAVOS}

El 1 de abril de 1500 Hamete Sillero y Ali Benajara, moros, vecinos de Guadix, se conciertan con Manuel de Ubeda para que Fátima, mora, que estaba secuestrada en Guadix y en poder del Condestable de Navarra pueda ser liberada. Manuel de Ubeda viajará a la corte para obtener una carta de los reyes en la que se ordenará dejarla en libertad a cambio de 20 ducados de oro "de buen peso e so justo valor". Actuó de testigo de este contrato Ali el Toy, moro, vecino de Guadix. El 15 de mayo Ali Benajara deja constancia por escrito que había comprado a Fátima, mora, mujer del Cazis, vecino de Andarax, que estaba en poder del Condestable de Navarra porque la tomó como esclava. El da poderes al licenciado Pedro Galán para que se traslade a la corte y obtenga la carta de los monarcas. En el momento que llegue la cédula real entregará el dinero estipulado para su libertad. 